\title{
AGRICULTURAL DEVELOPMENT AND FOOD SECURITY IN EASTERN EUROPE AND CENTRAL ASIA
}

\author{
Saule Burkitbayeva, William Liefert, and Johan Swinnen
}

The transition countries of Eastern Europe and Central Asia (ECA) are often jointly grouped (as they are in this chapter) because of their common institutional history. However, this is a very heterogeneous set of countries, in terms of their geography, culture, political systems, general economic development, and agricultural development and potential, as shown in Table 7.1. This table groups the countries by (sub)region, and we will use these groups to examine some of the main changes during transition and future potential developments.

These countries' economic and institutional transformation in the $1990 \mathrm{~s}$ and 2000s had a dramatic impact on their land use, food production, poverty, and food security. However, the pace and current stage of transition from socialist-planned to market economy differ strongly between countries. Some are now full market economies (such as the Eastern European countries within the European Union [EU]). However in others (such as Belarus and Uzbekistan), state regulation and control are still widespread. Yet, for the vast majority of countries in the region, the economic liberalization and transition caused dramatic changes in agricultural productivity, output, and consumption, as well as in the food system.

In many ECA countries, food security worsened and poverty increased during the transition process in the 1990s. However, since 2000 the ECA region has experienced significant growth and rising incomes, which have substantially reduced poverty and undernourishment and improved food security. Yet, undernourishment remains a problem in some of the poorer Caucasus and Central Asian states. Diets are also of low quality in many of these countries, resulting in micronutrient deficiencies. On the other hand, as ECA

This study was supported by the Methusalem program of KU Leuven and by the Economic Research Service of the US Department of Agriculture (USDA). The findings and conclusions in this chapter are those of the authors and should not be construed to represent any official USDA or US Government determination or policy. 


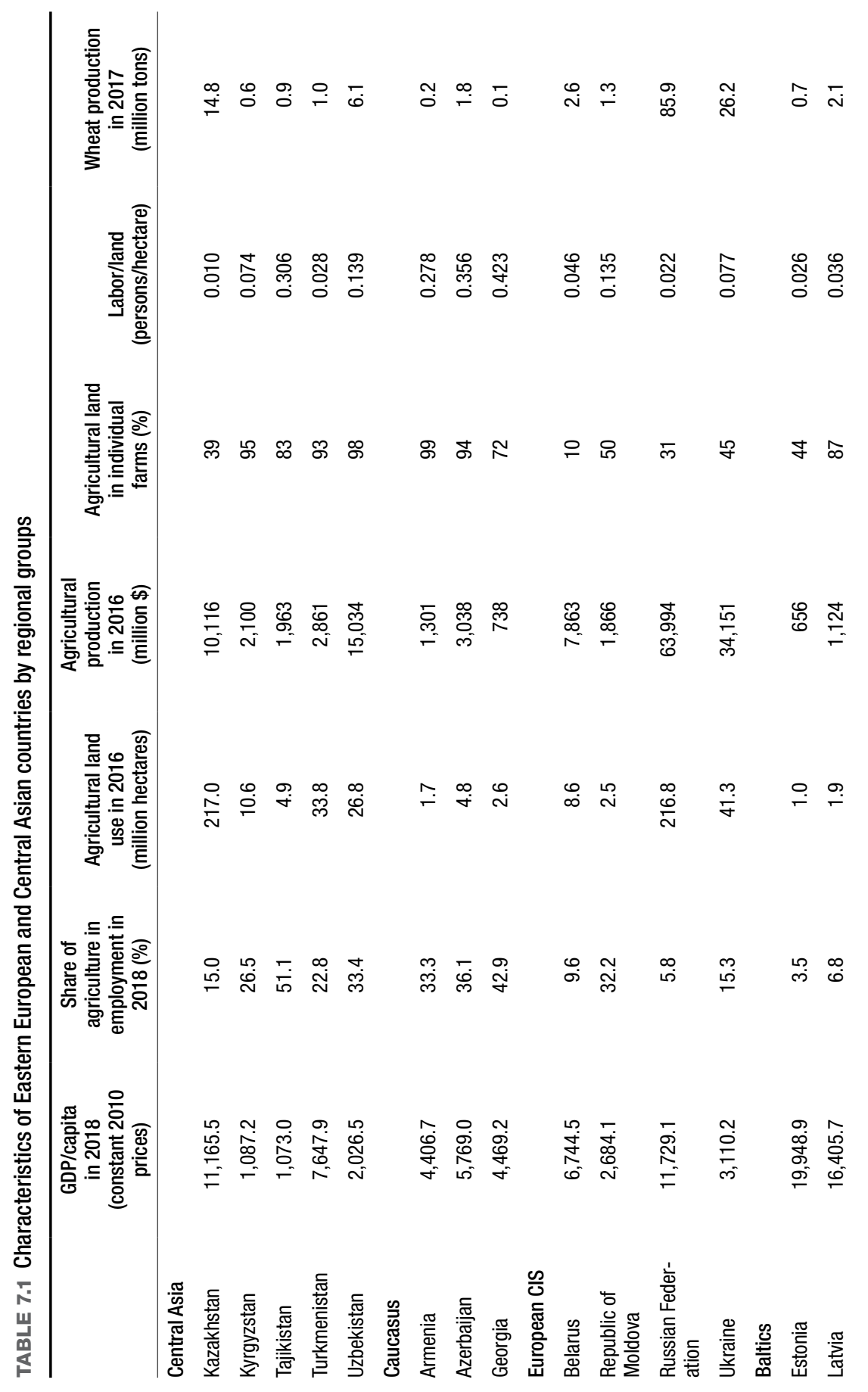




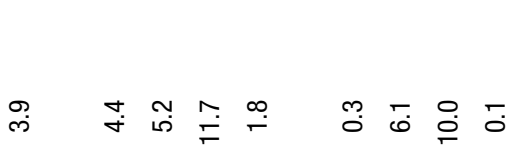

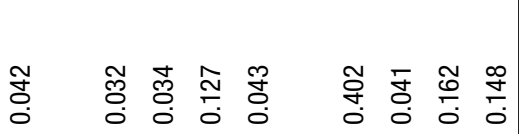

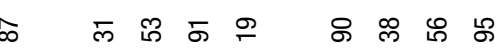

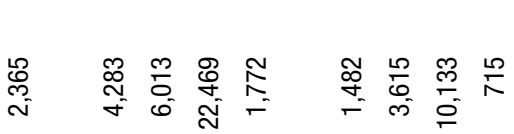

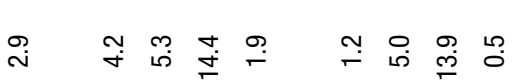

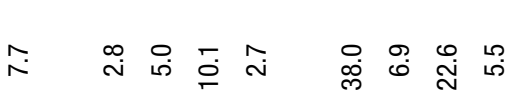

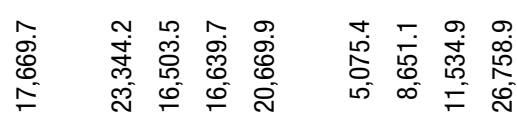

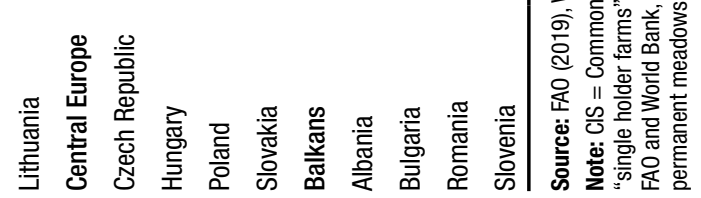


countries become richer and work becomes more sedentary, they are experiencing the challenge of overweight and obesity.

Eight Eastern European countries joined the EU in 2004, and three more have joined since. The agricultural development issues in these countries are now intertwined with the agricultural policies and general development challenges in the EU. These are quite different from the challenges and opportunities facing the transition countries farther east. For the purposes of this chapter, we therefore focus mostly on the non-EU transition countries and refer to these with the term ECA. However, within these, in more eastern ECA countries there is still much heterogeneity. Some of these countries have relatively higher incomes, have a comparative advantage in grain production, and are dominated (especially in land use) by large farms. Examples are the Russian Federation, Ukraine, and Kazakhstan. Another group have much lower incomes, face more severe food security problems, and are dominated by small-scale farms. Examples are Albania, Tajikistan, Kyrgyzstan, and Armenia. As Figure 7.1 shows, these poorer countries have many people working in agriculture and a large share of gross domestic product (GDP) from agriculture.

The ECA region is important both for its production potential and food security challenges on the consumption side. The region is a major food producer, in particular of grain and dairy goods. For example, it produces 12 percent of the world's milk, the same as the United States. The region's share in global agricultural trade is just below 10 percent $(8$ percent of world imports and 9 percent of exports). The region's status as a major producer and exporter of grain, and especially wheat, has attracted particular attention during the global food security debate over the past decade. The region accounts for 9 percent of world grain production and 18 percent of world wheat production (twice the US production of 9 percent). It is a major player in international grain markets, as it supplies 15 percent and 22 percent of global grain and wheat exports. The Russian Federation, Ukraine, and Kazakhstan (RUK) account for almost all of those exports.

Some specialists have argued that these countries could become a "breadbasket" for the world because of their potential to increase their already large volumes of grain production and exports by exploiting their "immense land and yield reserves" (Glauben et al. 2014). The decline in agricultural land use during the transition years of the 1990s was huge: between about 50 and 60 million hectares of land were abandoned, equal to around 50 percent of current land use within the RUK. However, there is considerable uncertainty about the economic and environmental feasibility of returning all this land to 
FIGURE 7.1 Share of agriculture in GDP and employment in 2016

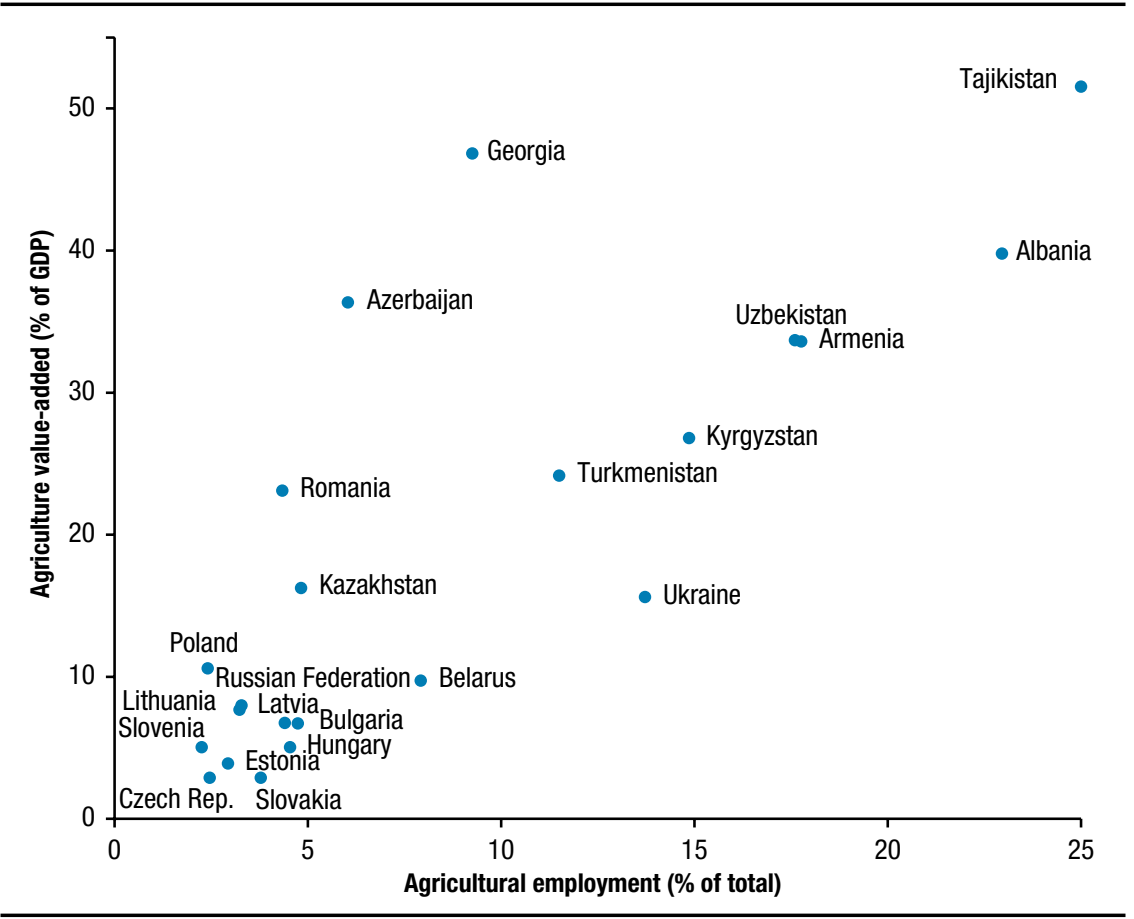

Source: World Bank (2019); ILO (2014).

Note: Data for Turkmenistan is for 2010.

production, as well as actual yield potential (Kraemer et al. 2015; Liefert and Liefert 2015).

Analyzing the region's potential to increase world food production, and how its agricultural development can contribute to world poverty reduction and food security, requires an understanding of its recent economic and agricultural transformation. Therefore we begin our chapter with a conceptual framework of the transition process and its implications, followed by an empirical examination of how agricultural production and productivity have evolved during transition and how these evolutions are related to changing farm structures and value chains. We then draw on these insights to discuss the future production and export potential. Then, we discuss the improvements, persisting problems, and new challenges in food security and nutrition of the region. Next, we discuss key agricultural, food, and nutrition security policies. The last section draws conclusions. 


\section{The Transition Process and Its Implications for Agricultural Development}

\section{Conceptual Framework}

The ECA countries have a common systemic and institutional history, and the move from a centrally planned to a more market-oriented economy that began around 1990 strongly affected all these states' agricultural sectors. To illustrate and examine key aspects of the agricultural transition process important for this chapter, we use a simplified version of the conceptual model of Swinnen and Rozelle (2006).

Consider a socialist farming system in which farms produce output $q$ with input $x$. Socialist farms were technically inefficient because (1) the government was typically less efficient than the market in how it allocated inputs, and (2) production was organized in state-owned collective farms, where managers and workers had less incentive to give optimal effort (Johnson and Brooks 1983). This second source of technical inefficiency-poor incentivesis illustrated in Figure 7.2a where the production functions are $q=f(x)$ for a farm operating privately in a market economy and $q_{o}=f_{o}(x)$ for a socialist farm. A second form of inefficiency (allocative) was that prices set by the government for inputs and output deviate from market prices. In ECA, planners typically set output-input price ratios higher than what a market-based system would generate, thereby subsidizing producers. The output-input combination of a farm facing the distorted prices represented by the relative (output-input) price line tangent to the production frontier is given in Figure 7.2a by point $A$. ${ }^{1}$ Price and market liberalization removed subsidies, and the farm moved from point $A$ to point $B$, with the (steeper) price line now representing market prices. Output and input use both fell. With property rights reform, the production function shifted from $f_{o}($.) to $f($.), that is, from point $B$ to point $C$.

However, the shift from $A$ to $B$ and $C$ did not go smoothly. Price liberalization and property rights reforms occurred in an environment characterized by imperfect information and weak institutional support. Transition, especially in the early reform years, was characterized by the breakdown of institutions of exchange and the rise of transaction costs. The disruptions can be modeled as a downward shift in the production function, to $q=f_{d}(x)$. A "perfect" property rights reform would induce a shift from point $B$ to $C$. However, with disruptions, the initial reform impact induced a move from point $B$ to $D$; instead

1 Even if planners did not set output prices high relative to input prices, price ratios within the closed economy would differ from those of goods traded on world markets. 
FIGURE 7.2 Transition process and its implications

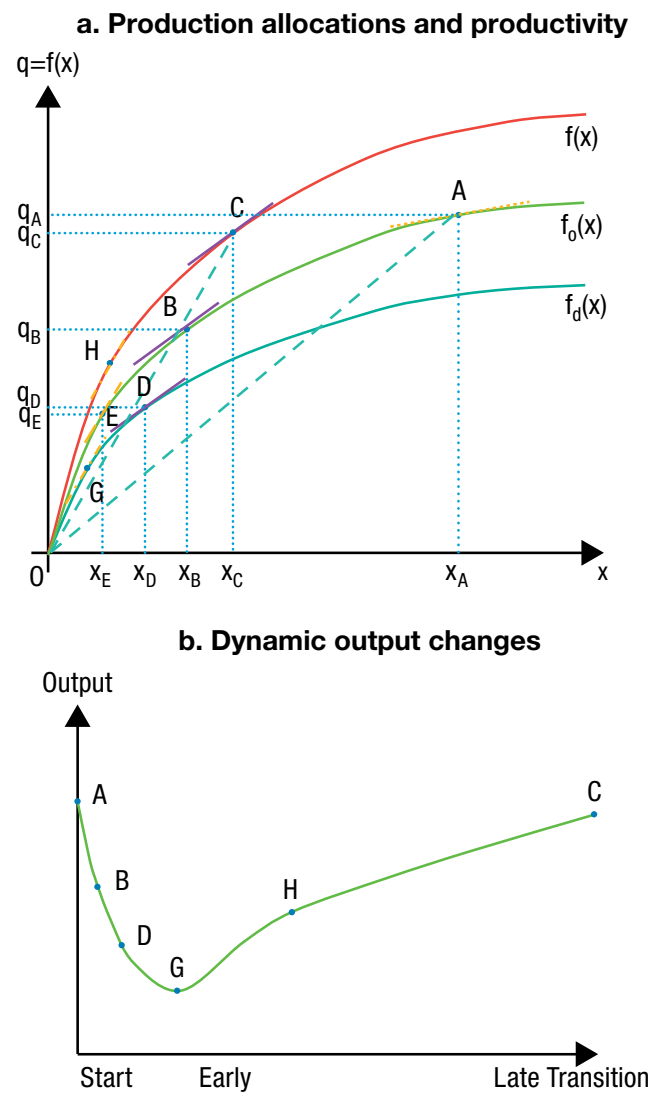

Source: Swinnen and Rozelle (2006). Reproduced by permission of Oxford University Press. This figure is not covered by the CC BY 4.0 license. See https://global.oup.com/academic/rights/permissions/?lang=en\&cc=gb.

of increasing inputs and output, property rights reforms caused a decline. These disruption effects were particularly important in countries with capitalintensive agricultural systems that were part of a complex network of input supply chains and output procurement or processing channels.

Price (and market) liberalization was also accompanied by disruptions due to the elimination of planning and the disorganization of institutions of exchange. Hence, when liberalization occurred, relative price shifts were driven not only by the move toward world market prices but also by institutional disruption caused by increased transaction costs. Rising transaction costs depressed output prices and raised farm input prices, thereby leading to deteriorating terms of trade (between output and input prices) at the farm level. This 
is reflected in a steeper relative price line and a move to point $E$ or $G$. While the mechanism is different from that caused by the disruptions associated with property rights reform, the effect is the same: a fall in input use and output.

There are also important dynamic effects, as the disruptions from transition were likely to have a different time sequence than the efficiency gains. In the words of Kornai (2000): "Transition calls for creative destruction. Because destruction is rapid, whereas creation proceeds more slowly, the two processes led to deep recession." Figure 7.5b illustrates this dynamic (with the letters consistent with those in Figure 7.2a). Prior to reform, farms are at point $A$. With price reform, output declines and farms move toward the allocatively efficient point $B$. Property rights reform initially mainly creates disruptions, such that in the early phase of transition, farms actually become more inefficient (point $D$ ). Market liberalization also creates initial disorganization, and the rising transaction costs exacerbate the falling terms of trade, moving farms to point $G$. As the reforms proceed and succeed, property rights reforms strengthen incentives, and the reorganization of input supply chains, output procurement, and processing channels improves the provision of inputs that originally were supplied by the state, allowing farms to increase their technical efficiency. Also, emerging and more effective institutions of exchange reduce transaction costs, improving farms' real terms of trade and allocative efficiency, inducing a shift from $G$ to $H$ and $C$.

After this dynamic process, technical and allocative efficiency increased at the end of the process, as average productivity. In Figure 7.2a, the average productivity, $q / x$, is represented by the slopes of the $O A$ and $O C$ lines. Both price and property rights reforms increase average productivity from $O A$ to $O C$, with the two reforms reinforcing each other in terms of productivity growth.

However, while average productivity increases, the input and output effects are ambiguous. Price and property rights reform work in opposite directions on input use and output. In Figure 7.2a, the net impact of the combined reforms on output is negative $\left(q^{C}<q^{A}\right)$, and on input use strongly negative $\left(x^{C}<<x^{A}\right)$. This net effect depends on the shape of the production function and on the relative size of the technical inefficiencies and prereform subsidies. Output and input use decline due to the price reform, but they increase with technical efficiency gains stemming from property rights reforms. This implies that efficient output and input use (including land) may well be (substantially) below the levels under the distorted socialist system.

In the rest of this section we present data that show an evolution consistent with this model, albeit the dynamics and levels of decline and recovery differed among countries and commodities. 


\section{Decline during Transition}

Actual agricultural production followed the $\mathbf{J}$-curve of Figure $7.2 \mathrm{~b}$ but with considerable variation among countries. In the first years of transition, gross agricultural output strongly decreased throughout ECA (Figure 7.3), varying from -25 percent in the Balkan countries to -45 to -55 percent in the Baltics and the European Commonwealth of Independent States (CIS, which includes the Russian Federation and Ukraine).

The large-scale reduction of subsidies resulted in a huge deterioration in agricultural producers' terms of trade: input prices rose relative to output prices, and output prices fell to world prices. For example, from 1991 to 1997, the terms of trade of Russian farms fell by about 75 percent, and input use (for example, fertilizer) declined by 70 percent (OECD 1999). Fertilizer use declined dramatically in all ECA countries in the early transition years, in response to price changes and supply chain problems. The decline in fertilizer use and crop prices generated a strong drop in crop yields. In most ECA countries, grain yields decreased between 20 and 30 percent (Figure 7.4).

Especially hard hit was the highly subsidized livestock sector. The downsizing of the livestock sector substantially reduced countries' demand for animal feed, which in turn lowered local grain production as well as imports of grain and soybeans needed for feed (Liefert and Swinnen 2002). As a result, countries such as the Russian Federation became meat importers and grain exporters (discussed more below). These countries thereby restructured their livestock and grain sectors consistent with their agricultural comparative advantage in the world (Liefert 2002).

\section{Recovery}

Countries also differed as to when recovery started. In some countries (for example, the Czech Republic, Poland, Albania), recovery began around 1993, while others (for example, the Baltics and European CIS) experienced more than a decade of falling output, with the rebound beginning as late as 2001. The production recovery was also uneven. As Figure 7.3 illustrates, current agricultural output in ECA varies from -30 to +30 percent of the pre-reform level, with the Caucasus and Central Asian regions doing best by this measure.

The magnitude of the output rebound has also varied by commodity. For example, wheat production in the region fell from 101 to 86 million tons from the beginning to end of the 1990 s but rose strongly in the following years. ${ }^{2}$

2 Tons are metric tons throughout. 
FIGURE 7.3 Evolution of gross agricultural output (GA0) (index, $1990=0$ )

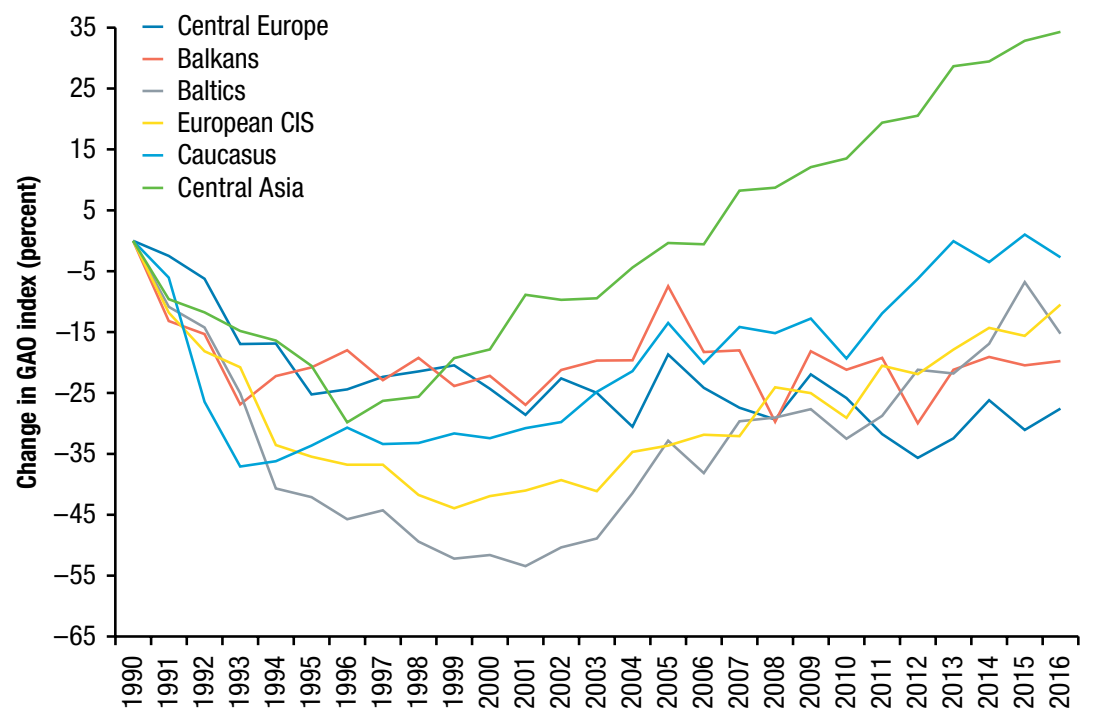

Source: Data from FAO (2019).

FIGURE 7.4 Evolution of grain yields (index, $1990=0$ )

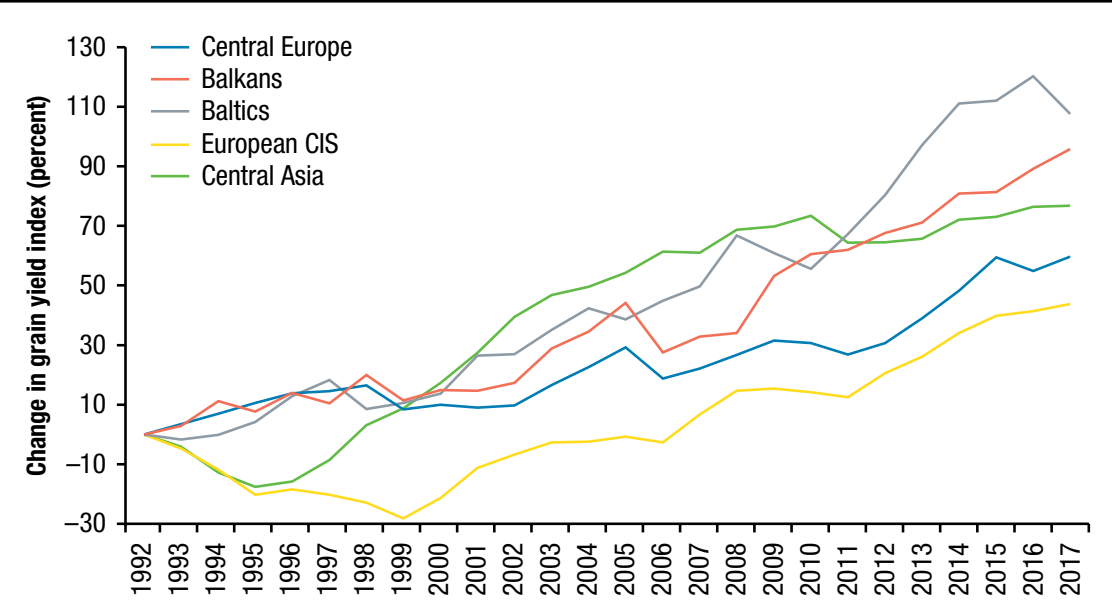

Source: Data from FAO (2019).

Note: The grain yield index is based on a three-year moving average of grain yields. 
TABLE 7.2 Agricultural production in Eastern Europe and Central Asia (ECA), 1989-2015 (three-year average in million tons)

\begin{tabular}{|c|c|c|c|c|c|}
\hline & 1989-1991 & 1995-1997 & 2001-2003 & 2007-2009 & 2013-2015 \\
\hline \multicolumn{6}{|l|}{ Grain production } \\
\hline Kazakhstan & 19.76 & 10.97 & 15.55 & 18.86 & 17.89 \\
\hline Russian Federation & 103.54 & 73.77 & 79.63 & 95.62 & 99.70 \\
\hline Ukraine & 46.96 & 31.33 & 32.91 & 42.83 & 63.03 \\
\hline \multicolumn{6}{|l|}{ Wheat production } \\
\hline ECA & - & 94.10 & 107.86 & 135.43 & - \\
\hline Kazakhstan & 11.29 & 7.71 & 12.31 & 15.35 & 14.17 \\
\hline Russian Federation & 44.17 & 36.43 & 43.90 & 58.29 & 55.90 \\
\hline Ukraine & 26.31 & 16.07 & 15.17 & 20.24 & 24.30 \\
\hline \multicolumn{6}{|l|}{ Meat production } \\
\hline ECA & - & 16.67 & 15.31 & 17.66 & - \\
\hline Kazakhstan & 1.55 & 0.85 & 0.67 & 0.87 & 1.57 \\
\hline Russian Federation & 9.86 & 5.33 & 4.7 & 6.25 & 9.07 \\
\hline Ukraine & 4.27 & 2.09 & 1.63 & 1.91 & 2.37 \\
\hline Poland & - & 2.84 & 3.09 & 3.38 & 4.07 \\
\hline \multicolumn{6}{|l|}{ Milk production } \\
\hline ECA & - & 91.56 & 87.63 & 91.02 & - \\
\hline Kazakhstan & 5.57 & 3.86 & 4.12 & 5.19 & 5.00 \\
\hline Uzbekistan & - & 3.48 & 3.80 & 5.43 & - \\
\hline Russian Federation & 54.48 & 36.42 & 33.26 & 32.37 & 30.80 \\
\hline Ukraine & 23.76 & 15.62 & 13.74 & 11.88 & 11.07 \\
\hline Poland & - & 11.82 & 11.90 & 12.34 & 12.97 \\
\hline
\end{tabular}

Source: FA0 (2015a); Kazstat (2016); Rosstat (2016); Ukrstat (2016).

Note: $-=$ data not available.

The increase was most spectacular in the main producing countries (the Russian Federation, Ukraine, and Kazakhstan; Table 7.2).

The recovery in grain production has been driven largely by increased yields and fertilizer use since 2000 (though use per hectare is still considerably below the pre-reform levels). Depending on the country and region, grain yields are currently between -10 and +35 percent of the pre-reform level. Figure $7.5 \mathrm{~b}$ and Figure $7.5 \mathrm{c}$ show the correlation between the growth in fertilizer use and grain yields in RUK.

Livestock production has not recovered as well in the larger ECA countries, consistent with the argument that these countries have a comparative 
FIGURE 7.5 Land use, fertilizer use, and grain yields in the Russian Federation, Ukraine, and Kazakhstan

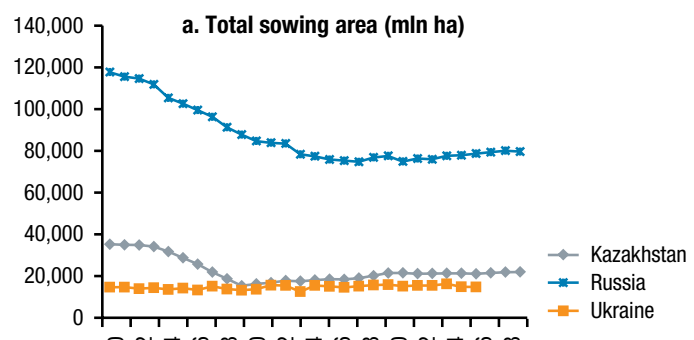

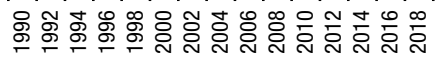

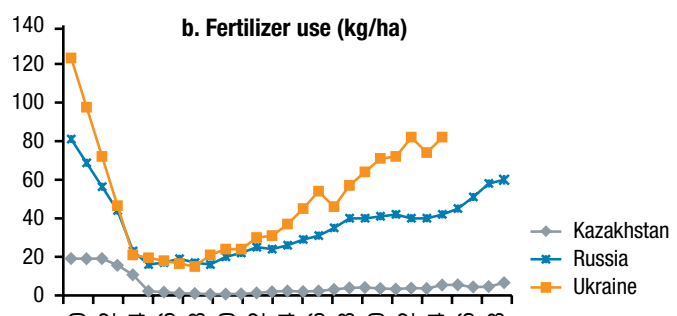

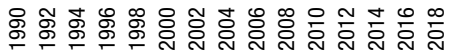

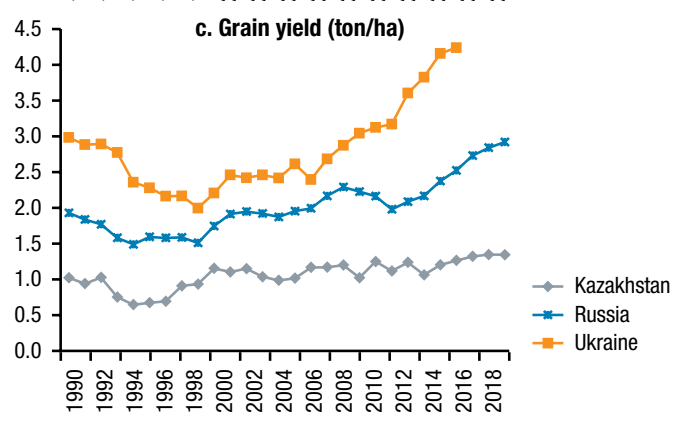

Source: Rosstat (2019); Kazstat (2019); Ukrstat (2019).

Note: Yields are expressed as three-year moving averages.

disadvantage in producing livestock products. In many ECA countries, meat and dairy output in 2013-2015 was still below the levels of 1989-2001. After falling from 20.8 million tons in 1992-1994 to 15.0 million tons, ECA meat production rose to 19.8 million tons in 2010-2012. However, that figure is still well below the late socialist level. Total ECA milk output had the same trajectory, dropping from 107 million tons in 1992-1994 to 85 million tons in 1998-2000, and then rising to 91 million tons by 2012-2014. Yet, that volume is also still below the pre-reform level. 
FIGURE 7.6 Land and labor productivity in Eastern Europe and Central Asia a. Eastern Europe
and European CIS

b. Caucasus and Central Asia
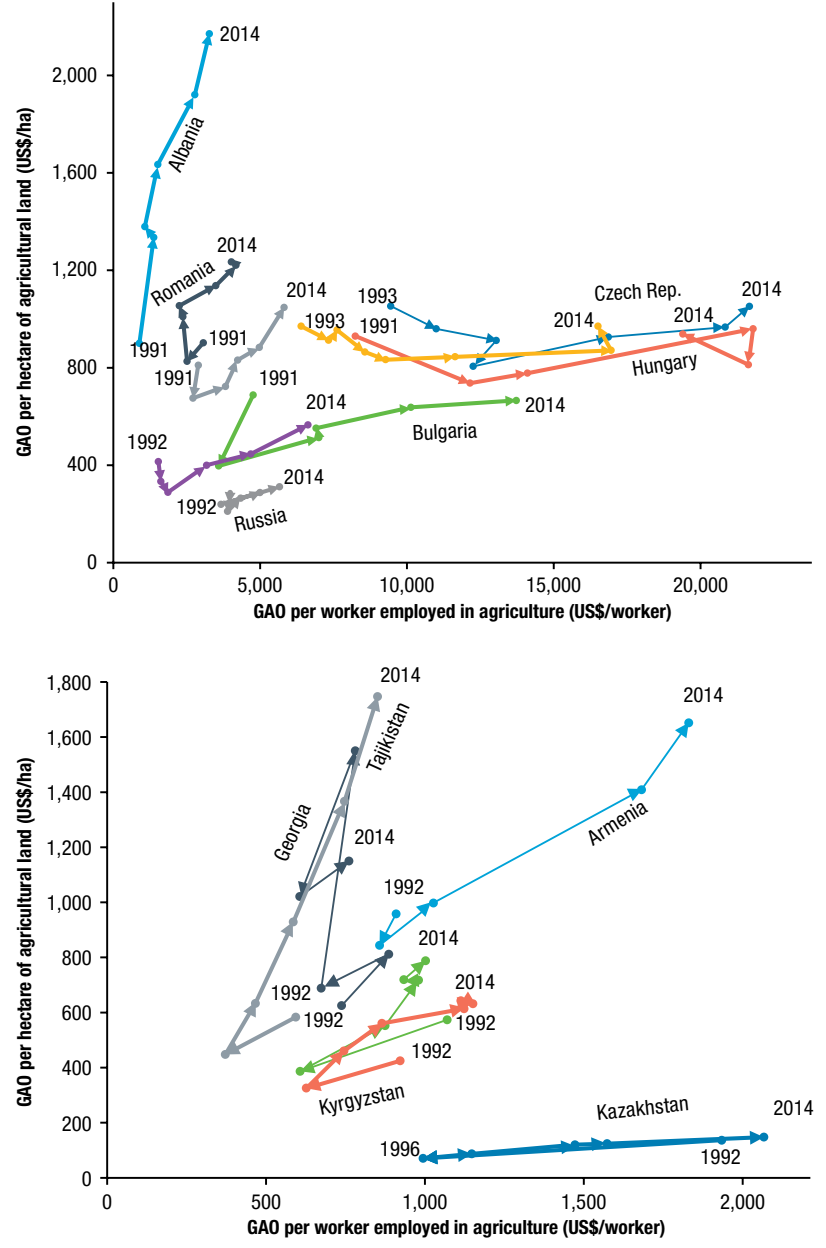

Source: FAO (2019); ILO (2014).

Note: $\mathrm{GAO}=$ gross agricultural output. Agricultural land refers to arable land and permanent crops. Gross production value is measured in constant 2004-2006 million US dollars.

\section{Diverging Growth Patterns}

As already emphasized, the development of agriculture in recent years differs quite strongly among countries. The heterogeneity in recovery and growth patterns is clearly illustrated with the use of labor-land productivity dynamics, following Hayami and Ruttan (1971). Figure 7.6 summarizes the labor and land productivity development. 
One growth pattern is that of an agriculture sector where large farms play a significant role and growth has come mostly from (very strong) labor productivity growth. This pattern has been followed by Slovakia, the Czech Republic, and Hungary, while recently Bulgaria and Ukraine are joining it.

A very different pattern is followed by poorer countries dominated by small farms (such as Albania, Armenia, Tajikistan, Georgia, and Kyrgyzstan). However, in these countries output per hectare has risen much more than in the first pattern, due to intensive use of inputs on smaller farms.

Countries such as Poland (and to a lesser extent Romania) are a mix, as growth has come from both higher land and labor productivity, though productivity growth has been limited in both directions. These countries are characterized by a majority of smaller farms, a sizable share of large farms, and relatively rich economies (compared with the ECA average).

To sum up, in the ECA region, a high (or low) land-labor ratio is more likely to be associated with a high (or low) capital-labor ratio and growth in labor productivity (or land productivity) as a result of labor shedding (absorption).

\section{Growth Patterns and Farm Structures}

As is clear from the discussion above, changes in countries' agricultural productivity are associated with their farm structures. The ECA region is now characterized by strong heterogeneity in farm structures: in some countries smallholders and family farms dominate, while in others large farms play an important role. There is no simple East-West divide in this. In Central Europe, large farms hold most of the land in Slovakia and the Czech Republic, while family farms dominate in Poland and Slovenia. In Central Asia, large farms are important in the northern parts of Kazakhstan while small farms are significant in southern Kazakhstan, Kyrgyzstan, and Tajikistan.

The emergence of different farm structures is to an important extent "endogenous" to the transition process. The nature of the commodity and factor market imperfections appears to have played a significant role in the evolution of the farm structures. Large farms dominate in extensive crop cultivation (including grains) in the Russian Federation, Ukraine, and Kazakhstan. Many of these farms are part of large-scale vertically integrated agroholdings. These farms and agribusiness structures have emerged as a consequence of the specific privatization programs in these countries, the simultaneous financial constraints in agriculture, and the inflow of capital from other sectors of the economy (Serova 2007). Vertical integration resulted from the need to 
overcome financial constraints at the farm level and the better access to capital in commodity trading (World Bank 2005; Swinnen 2009). The shift to small-scale farming has been lowest in labor-extensive production systems and strongest in labor-intensive production systems. Small farms have also served as a labor-absorbing institution during transition, thereby contributing to a divergence of farm structures (Dries and Swinnen 2002; Swinnen, Dries, and Macours 2005). This was most important in the poorer countries, so there is some correlation between farm sizes and GDP per capita (Figure 7.7). ${ }^{3}$

In Central Europe, a rapid restructuring of farms combined with labor shedding has been strongly associated with labor productivity growth (Figure 7.8). In other ECA countries, agricultural labor productivity (ALP) was substantially lower and agriculture provided a buffer during transition, in terms of both labor allocation and food security. In some of the poorest countries, such as Tajikistan, agricultural employment remains very high (Figure 7.1) with high labor use on small farms. In fact, Figure 7.9 illustrates the negative correlation between the share of smallholder farms and labor productivity in ECA agriculture.

Today, most countries have a mix of large- and small-scale farms. Some of these differences reflect disparities in natural resources or commodity characteristics. ${ }^{4}$ Table 7.3 documents the share of smallholders in land use and agricultural production. For most CIS countries, statistics distinguish between "agricultural enterprises," "individual farms," and "households." For the Central and Eastern European (CEE) countries, statistics distinguish "family farms" (as a subcategory), "farms less than 2 hectares," and larger farms. If we identify "smallholders" as "households" in CIS and "farms less than 2 hectares" in the CEE, these farms use less than 3 percent of land in CEE and have produced around 6 percent of output in recent years. The main exception

3 Slovenia is an outlier in Figure 7.7, with high incomes and only small farms. This is because in Slovenia, as part of the former Yugoslavia, farms were never collectivized into large-scale communist farms as in the other ECA countries (the other exception being part of Poland, where small-scale farms also survived Communist rule).

4 There is also remarkable variation in how farms have adjusted labor use during transition. In some countries, farms absorbed labor, while in other countries farms massively shed labor, even in the early years of transition. The differences are large: from a strong increase in some of the Central Asian countries to a dramatic decline of more than 50 percent of official employment in Central Europe. We observe such large differences not only between very different regions, but also within regions and even within countries. For example, on average the outflow of labor in Poland was much lower than in neighboring Slovakia and the Czech Republic, but within Poland there were huge differences between regions (Dries and Swinnen 2004; Swinnen, Dries, and Macours 2005). See also the discussion in the next section. 
FIGURE 7.7 GDP per capita versus share of large farms in land use in Eastern Europe and

\section{Central Asia}

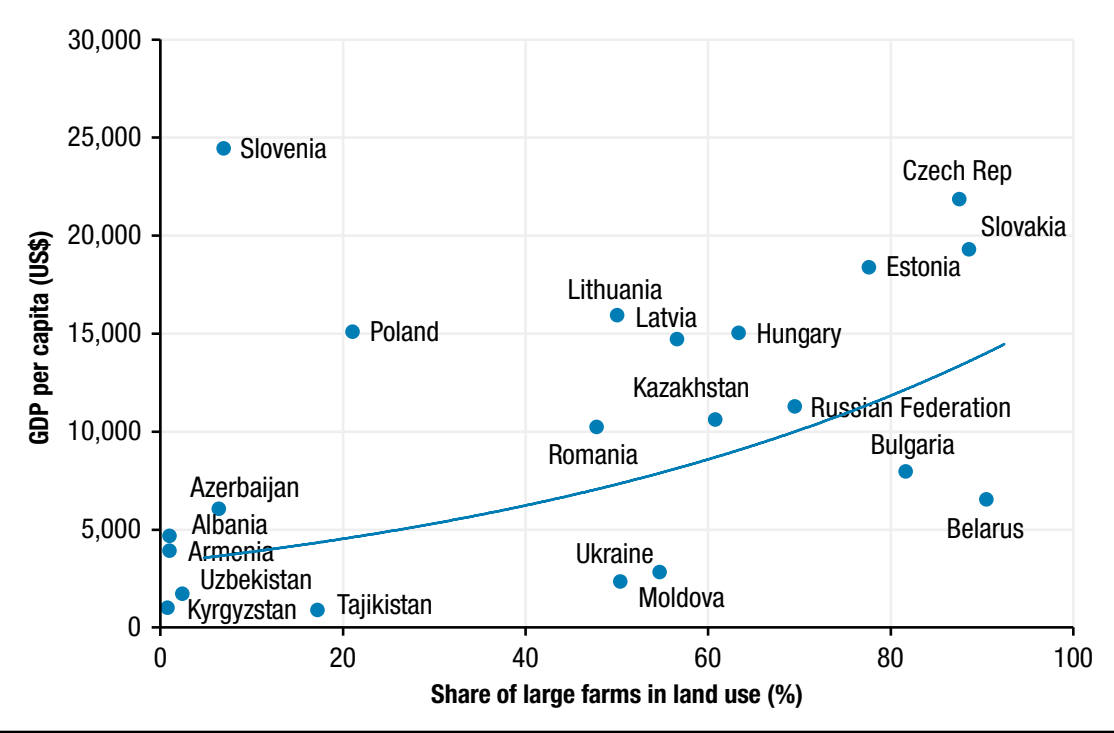

Source: World Bank (2019); Eurostat (2018).

Note: Data for Central and Eastern Europe (CEE) are for 2016; data for the Commonwealth of Independent States (CIS) are for 2015. GDP = gross domestic product.

FIGURE 7.8 Agricultural labor productivity (ALP) (index, $1990=0$ )

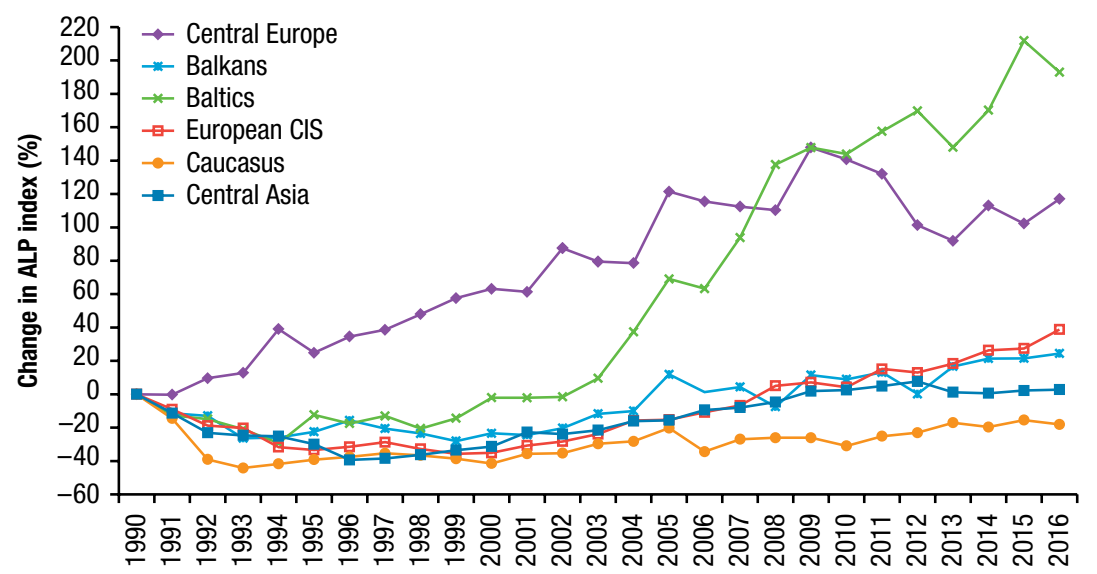

Source: ILO (2014); World Bank (2019); FA0 (2019). 
FIGURE 7.9 Agricultural labor productivity and smallholders in Eastern Europe and Central Asia

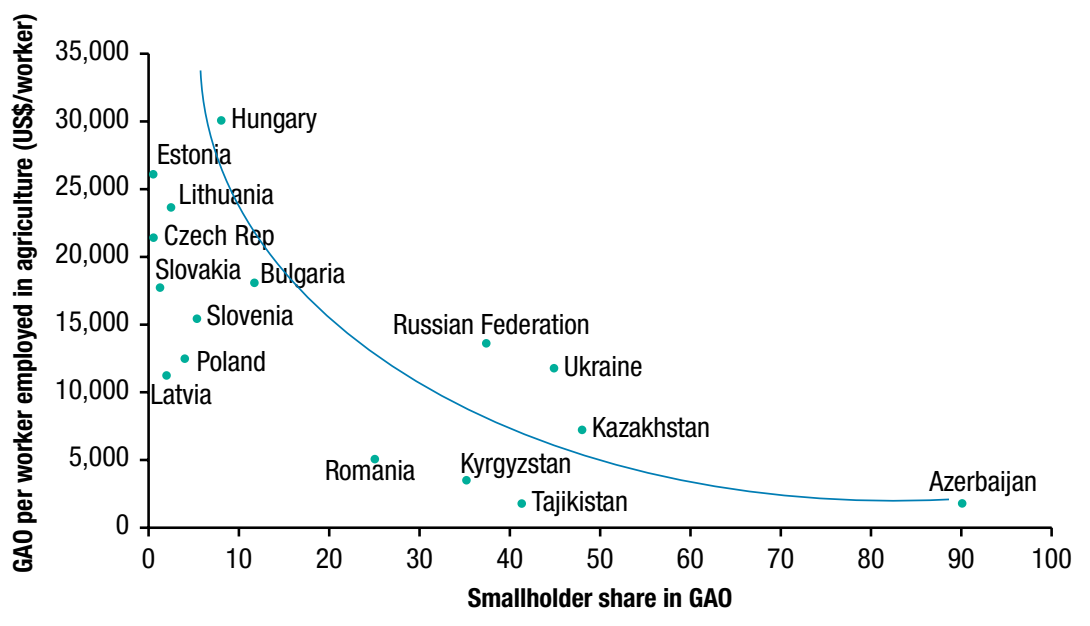

Source: Eurostat (2018); Burkitbayeva and Swinnen (2018); FA0 (2019).

Note: $\mathrm{GAO}=$ gross agricultural output. "Smallholders" refers to "farms with less than 2 ha of land" for CEE and "households" in CIS statistics.

is Romania, where they use 12 percent of land and produce 24 percent of output.

Household producers are more important in CIS. On average, they use 13 percent of land and produce 50 percent of output. As the output-land indicator shows, smallholders typically produce around twice as much output per unit of land in both CIS and CEE.

These transition processes thus contributed to large differences in labor productivity in agriculture. Figure 7.9 illustrates how today's agricultural labor productivity, on average, is much higher in countries with fewer smallholders.

Almost everywhere, the importance of smallholders in agriculture has fallen and often strongly so, as shown in Figure 7.10 for CIS and CEE on average. Between 2003 and 2016, on average, the share of smallholders in both land use and output fell by more than 50 percent in Eastern Europe (Figure 7.10). With one exception (Romania), their share in land use is now less than 5 percent in all Eastern European countries. In the CIS, their share

5 Family farms as a whole are much more important in CEE, using the majority of the land in several countries and producing between 17 and 91 percent of output. There are large differences between countries, with family farms more important in Poland and Slovenia and less important in Slovakia and the Czech Republic (Table 7.1). 
TABLE 7.3 Area used and agricultural production by smallholders and family farms

\begin{tabular}{|c|c|c|c|c|c|}
\hline & \multicolumn{2}{|c|}{ Smallholders } & \multicolumn{2}{|c|}{ Family farms } & \multirow[b]{2}{*}{$\begin{array}{c}\text { Smallholde } \\
\text { output/land } \\
\text { ratio }\end{array}$} \\
\hline & $\begin{array}{c}\text { Utilized } \\
\text { agricultural area } \\
\text { (\% of total) }\end{array}$ & $\begin{array}{l}\text { Agricultural } \\
\text { output } \\
\text { (\% of total) }\end{array}$ & $\begin{array}{c}\text { Utilized } \\
\text { agricultural area } \\
\text { (\% of total) }\end{array}$ & $\begin{array}{l}\text { Agricultural } \\
\text { output } \\
\text { (\% of total) }\end{array}$ & \\
\hline Bulgaria & 1.6 & 7.6 & 38.0 & 51.8 & 4.7 \\
\hline Czech Republic & 0.1 & 0.5 & 30.5 & 22.8 & 5.0 \\
\hline Estonia & 0.2 & 0.3 & 44.3 & 29.3 & 1.5 \\
\hline Latvia & 0.6 & 1.6 & 87.4 & 80.1 & 2.7 \\
\hline Lithuania & 1.1 & 2.3 & 86.8 & 77.8 & 2.1 \\
\hline Hungary & 2.0 & 5.6 & 53.0 & 48.7 & 2.8 \\
\hline Poland & 2.9 & 3.5 & 90.9 & 91.1 & 1.2 \\
\hline Romania & 12.3 & 23.9 & 55.7 & 70.5 & 1.9 \\
\hline Slovenia & 4.0 & 6.2 & 94.6 & 89.9 & 1.6 \\
\hline Slovakia & 0.4 & 0.8 & 19.4 & 17.4 & 2.0 \\
\hline Average CEE & 2.5 & 5.2 & 60.1 & 57.9 & 2.1 \\
\hline Russian Federation & 4.3 & 37.4 & 30.5 & 48.5 & 8.7 \\
\hline Ukraine & 30.5 & 44.9 & 45.3 & - & 1.5 \\
\hline Belarus & 7.6 & 19.8 & 9.5 & 21.7 & 2.6 \\
\hline Republic of Moldova & - & - & 49.6 & 58.0 & - \\
\hline Azerbaijan & - & - & 93.6 & 92.7 & - \\
\hline Kazakhstan & 1 & 52.1 & 39.2 & 79.4 & 52.1 \\
\hline Kyrgyzstan & 10.2 & 36.3 & 95.2 & 98.1 & 3.6 \\
\hline Tajikistan & 25.0 & 41.3 & 82.7 & 94.2 & 1.7 \\
\hline Uzbekistan & 12.9 & 65.0 & 97.6 & 98.0 & 5.0 \\
\hline Average CIS & 13.1 & 49.7 & 60.4 & 73.8 & 3.8 \\
\hline
\end{tabular}

Source: Burkitbayeva and Swinnen (2018). Reprinted by permission of the publisher; this table is not covered by the CC BY 4.0 license.

Note: $-=$ data not available; CEE $=$ Central and Eastern European countries; CIS = Commonwealth of Independent States. Numbers for smallholders refer to "farms with less than 2 ha of land" for CEE in Eurostat statistics and "households" in CIS statistics. Numbers for family farms refer to "single holder farms" for CEE in Eurostat statistics (latest available year 2013) and "households" and "individual farms" combined for CIS statistics.

in output declined by 17 percent between 2000 and 2015, and the decline was most rapid in recent years ( -10 percent between 2010 and 2015).

The more extensive reduction of smallholders in the past decade in CEE (compared with CIS) is most likely a combination of several effects. First, stronger growth in CEE was associated with stronger demand for labor (or, in other words, the supply of better-paying jobs) in the rest of the economy. Second, while CEE agriculture as a whole benefited from increased subsidies through the EU's Common Agricultural Policy, these subsidies were biased 
FIGURE 7.10 Share of smallholders in production in Eastern Europe and Central Asia

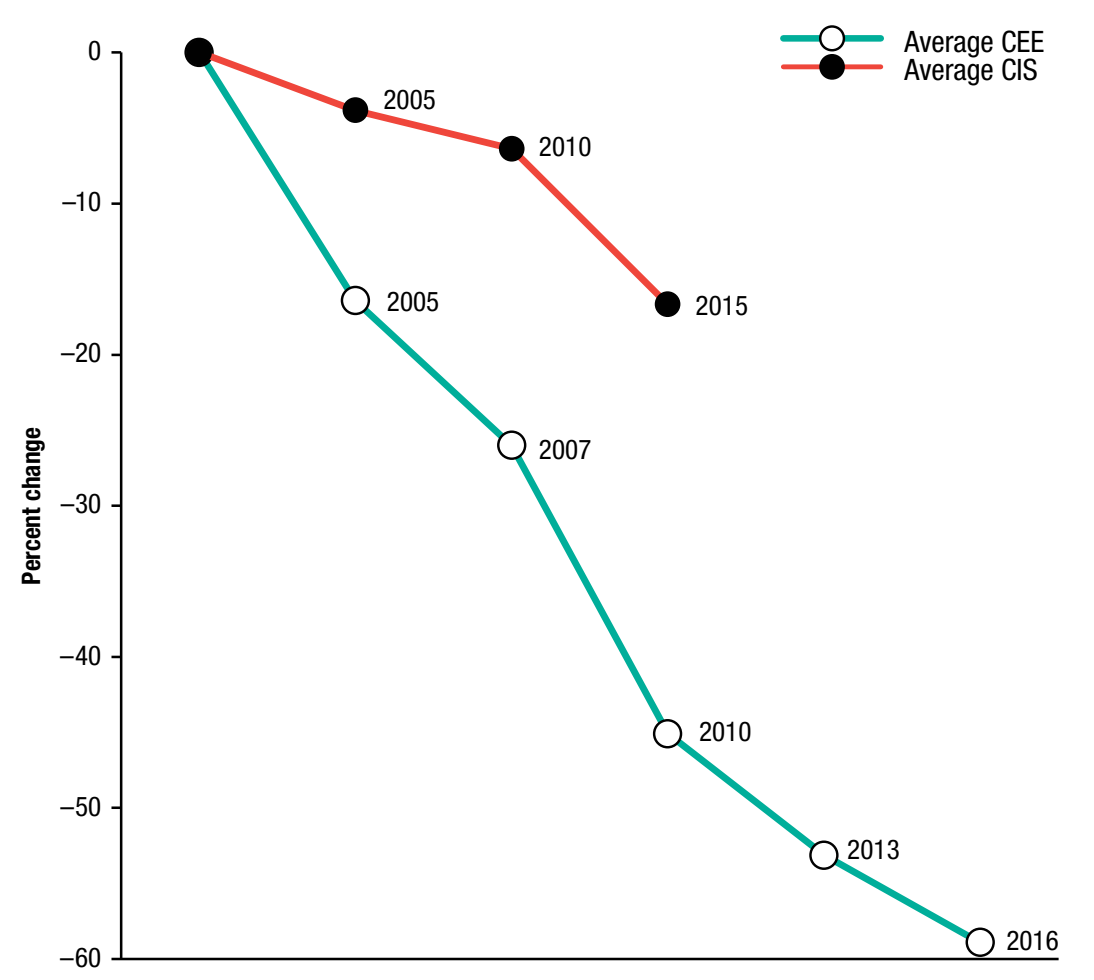

Source: Burkitbayeva and Swinnen (2018); Eurostat (2018). Reprinted by permission of the publisher; this table is not covered by the CC BY 4.0 license.

Note: $\mathrm{CEE}=$ Central and Eastern Europe; $\mathrm{CIS}=$ Commonwealth of Independent States. For CIS, percent change starts with $2000=0$; for CEE, percent change starts with $2000=0$. "Smallholders" refer to "farms with less than 2 ha of land" for CEE and "households" in CIS statistics.

toward larger farms and stimulated higher input costs (including land prices), both of which may have hurt smallholders' competitive position. Third, EU accession required the introduction of strict safety and quality standards throughout the value chains, both through public (EU) regulations. Fourth, (the expectation of) EU accession stimulated large inflows of foreign direct investment (FDI) into the CEE economies and the food system. This was associated with the introduction of stringent private standards that were sometimes difficult for smallholders to implement. Fifth, extensive FDI in the food system also involved the arrival of hard discounters in CEEs, which pushed down the price of basic products, including food, thereby reducing the attractiveness of "make versus buy," that is, household subsistence food production. All these factors have contributed to the decline of smallholders. 


\section{Market Imperfections, Value Chains, and Investments in Agribusiness and Food Companies}

Agricultural productivity growth has been strongly influenced by valuechain investments, up- and downstream from the farms. These investments have been motivated by a combination of market imperfections (especially in capital, inputs, and technology markets) and the introduction of quality standards by modern food processing and retail companies. Access to output and input markets was an important constraint for farms in ECA and still is in some countries. The evolution of the food value chain is discussed in Chapter 12, whereas the role of contract farming between food processors/agribusiness/supermarkets and farmers is discussed in Chapter 11.

Private investments in agribusiness, food processing, and retail companies led to important restructuring in production, trading, and marketing systems and in the integration of farms in value chains in ECA. Contracting and vertical coordination in these supply chains played an important role in this process (Gow and Swinnen 1998). Dries et al. (2009) document the rapid growth of vertical coordination in Eastern European value chains to overcome input and capital constraints of the farms and ensure high-quality raw material for the dairy processors. One reason for the emergence of large vertically integrated agroholdings in the Russian Federation, Ukraine, and Kazakhstan was to counter the high transaction costs and supply uncertainty that existed because of weak infrastructure (physical and institutional) and commercial support services for market agriculture.

Vertical coordination in the ECA region included a variety of institutional innovations, such as provision of credit, inputs, and quality control. These programs are believed to have triggered major technology transfer, productivity growth, and improvements in product quality at the farm level (Gow, Streeter, and Swinnen 2000; Dries and Swinnen 2004, 2010; Noev, Dries, and Swinnen 2009).

Investments in the value chains often came from foreign companies, especially in Eastern Europe where Western European agribusiness, food processing, and retail companies were eager to invest. They were attracted by the closeness of the markets, the relatively high incomes of the population, and the (expected) integration into the EU. In the Russian Federation, some of the most important investments in the value chains came not from foreign companies but from domestic financiers who got access to capital from profits in 
other sectors, such as trading, banking, or oil and gas. ${ }^{6}$ These investments reduced capital constraints and thereby made access to inputs and technology easier and stimulated productivity growth in these chains.

Last, studies on the dynamics of smallholder integration in modern value chains in ECA find that (1) smallholders integrated into supply chains were upgrading in terms of technology, productivity, and size; and (2) the ones that were not growing were older households, keeping animals for household consumption and without product standards required by the market (Van Herck and Swinnen 2015). This process of small though upgrading farms led by younger and more entrepreneurial types and the decline of small farms run by the elderly, either because they retire or can no longer (physically) farm, seems to be a common development across the more developed countries in ECA. In contrast, small poor farmers remain very important in the poorest ECA countries, such as Tajikistan, where investments in value chains are lagging.

\section{Constraints on Land and Water Use}

Transition led to substantial changes in land use. Land abandonment was caused by (1) the reduced profitability of farming from the drop in agricultural subsidies and move to market prices and (2) uncertainty on land property rights. Both developments affected how much land was used and how intensely it was cultivated (that is, how many other inputs were used along with it in production). Vranken et al. (2011) showed how land plots with uncertain ownership were more likely to be left abandoned or used less intensively. Land abandonment was widespread in some countries. ${ }^{7}$ According to Kraemer et al. (2015), 45 percent of cropland in the former Soviet Union was converted to grassland between 1990 and $2000 .^{8}$

6 In the RUK countries, much of the investment financing (and management) of the agroholdings came from sectors outside of agriculture.

7 Official data do not always present an accurate picture of the changes because they often do not distinguish between cropland and pastures.

8 For Russia alone, estimates of cropland abandonment vary from 20 million hectares to more than 40 million hectares: the estimate is 43.5 million hectares by Lambin et al. (2013), 32 million hectares by Alcantara et al. (2013), and 20 million hectares by Ioffe, Nefedova, and Zaslavsky (2004). The disparities arise for several reasons: differences in the time periods and regions of measurement, the definitions of land abandonment used, and the quality of the data and heterogeneity of abandonment patterns in the regional estimates (Alcantara et al. 2013). 
Estimates of abandoned cropland in RUK during transition vary between 50 and 60 million hectares (Schierhorn et al. 2013; Meyfroidt et al. 2016; and RUK official statistics).

In addition, the process of transition led to a significant deterioration of infrastructure, most notably involving irrigation. Irrigation is a major component of agricultural production, particularly in certain arid regions of Central Asia and the Caucasus subregion.

Irrigation problems were reinforced in some of these regions in Central Asia and the Caucasus by the shift to household farms. This process led to land fragmentation, which brought further challenges related to irrigation, as the existing infrastructure had been constructed for much larger units of production, such as kolkhozes and sovkhozes (Lerman 2010; Akramov and Shreedhar 2012). On-farm irrigation was left to be managed by smaller plots, creating problems in access to and management of irrigation infrastructure. This led to a complex set of formal and informal arrangements and problems, such as rent seeking, information asymmetry, and distrust between community members (Akramov and Omuraliev 2009).

In order to deal with the changing landscape of farm structures and irrigation needs, water users associations (WUAs) were established in some countries of Central Asia and the Caucasus. These were intended to regulate water allocation at the community level and ensure operation and maintenance of the on-farm irrigation and drainage infrastructure via in-kind and cash contributions from the members. However, due to weak governance structures, financial mismanagement, and dwindling membership numbers, these proved to be largely unsuccessful (Wegerich 2008; Akramov and Shreedhar 2012; Zinzani 2015). In some countries, the introduction of irrigation water fees led to "elite capture" allowing certain groups to gain better access to irrigation (Akramov and Omuraliev 2009). Some argue that the failure of WUAs, particularly in Central Asia, is associated with the way they were established-via top-down approaches that precluded grassroot initiatives, experience, and incentive among the members (Abdullaev et al. 2010; Abdullaev and Atabaeva 2012). Most recent experimental evidence from Uzbekistan and Kazakhstan by Amirova, Petrick, and Djanibekov (2019) calls into question the top-down approach in current water policies of the region and suggests the superiority of endogenous cooperation and hence encourages the implementation of self-governed water management systems.

Problems with irrigation infrastructure also compound challenges associated with soil quality, salinization, and waterlogging. With the increasing frequency of weather extremes and aridity, improving irrigation water 
management and efficiency of irrigation infrastructure remains important, not only for raising agricultural productivity, but also for improving the climate resilience of the sector.

\section{Potential for and Constraints to Feeding the Region (and the World)}

Agricultural output can grow through the use of more inputs (extensive growth) or through increased productivity (intensive growth) (Babcock 2015). As explained above, agricultural productivity covers many inputs, including labor and knowledge (human capital). However, the vast bulk of the literature on agricultural productivity in the ECA region focuses on land use (especially for grain) and yields. Many studies have pointed out that the widespread cropland abandonment in the ECA countries during the transition years represents large untapped agricultural production potential (EBRD and FAO 2008; Lambin and Meyfroidt 2011; Glauben et al. 2014; Meyfroidt et al. 2016).

\section{Land Use Potential}

There has been some recultivation of abandoned cropland in the past decade, primarily in areas with good agronomic conditions. However, land use is still much lower than during the pre-reform period. Compared with 1990, land use in 2015 was still 40 percent and 30 percent lower in Kazakhstan and the Russian Federation, though about the same in Ukraine (Figure 7.5a).

The recultivation of all idled cropland would dramatically increase total crop area. However, much of the abandoned land was farmed during the socialist period only because of the decisions of state planners, backed by heavy subsidies. Hence, there is no strong economic rationale for returning all this land to production. Liefert and Liefert (2015) find that most of the Russian Federation's abandoned grain area was in high-cost regions of the country, especially in the north and east. Uzun et al. (2014) estimate that returning 19 million hectares of abandoned cropland to production in the Russian Federation would require grain export prices to rise to $\$ 400$ per ton (with the average world market price for wheat from 2012-2015 being $\$ 200$ per ton). The authors also point out that the degree of grain recultivation on abandoned croplands in northern European Russia, that is, outside the fertile black soil areas, is low mainly because of biophysical constraints. Liefert and Liefert (2015) also argue that cropland recultivation in the Russian Federation might not necessarily lead to much additional grain production because of competing land demand from other crops, particularly oilseeds. 
Moreover, crop area that was abandoned in the 1980s or 1990s is often currently infested with deep-rooting vegetation that renders recultivation expensive (Larsson and Nilsson 2005). Such costs should be kept in mind because by 2012, approximately 3.5 million hectares of agricultural land from the Soviet period was covered by forest in European Russia alone (Potapov et al. 2015). The secondary vegetation is important for biodiversity and ecosystem services (Kamp et al. 2011), and it stores substantial amounts of carbon in soil and vegetation, much of which would be emitted to the atmosphere with recultivation (Schierhorn et al. 2013; Kurganova, Lopes de Gerenyu, and Kuzyakov 2015).

Hence, it appears that only a fraction of the abandoned ECA (and mainly RUK) cropland can be put back into production without significant costs or major environmental trade-offs. Meyfroidt et al. (2016) identified that from 60 million hectares of RUK crop area that was initially abandoned, about 12 million hectares had been returned to production by 2009 and that only 8.5 million hectares of the remaining idled land qualifies economically for being returned to the plow, in that the land has high soil quality and recultivation would involve low environmental trade-offs and few accessibility and socioeconomic constraints (5.3 million hectares in the Russian Federation, 2.4 million in Kazakhstan, and 0.9 million in Ukraine).

Agroenvironmental and socioeconomic constraints limit reusing abandoned cropland in RUK. The vast bulk of high-quality land is already back in cultivation. Other more marginal lands may be more suitable for other uses, such as livestock grazing, development of a livestock fodder base, or ecosystem services.

\section{Yield Potential}

Since 2000, there have been significant improvements in farm access to yield-increasing inputs used in grain production. Fertilizer use has recovered significantly from its low point in the late 1990s, especially in the Russian Federation and Ukraine. Important structural and institutional changes over the past decade helped to overcome systemic constraints in the major grain-producing regions and contributed to the emergence of large-scale and vertically integrated farming operations, such as the agroholdings (Gataulina et al. 2005; Serova 2007; Swinnen 2009; Nefedova 2016). Since 2005, the Russian government has also increased subsidies to agriculture (Liefert and Liefert 2012). Increased government support, strong depreciation of the ruble in 2014/2015 (largely because of falling world oil prices, which cut the Russian Federation's export earnings), and high agricultural world market 
prices have all contributed to increased investments in booming exportoriented Russian grain production (Kingwell et al. 2016).

Increasing investments and higher export returns have helped to generate significant growth in fertilizer use and yields. Grain yields started recovering in the late 1990s and have since risen in the RUK by 50 to 70 percent. However, current fertilizer use per hectare is still considerably below the pretransition levels, reflecting, among other things, the cut in the large fertilizer subsidies and possibly inefficient use of fertilizer in the planned socialist economy. Figure $7.5 \mathrm{~b}$ also shows how current fertilizer use per hectare is much higher in Ukraine than in the Russian Federation, and substantially higher in the Russian Federation than in Kazakhstan.

Several studies have identified significant potential for yield growth in RUK grain production due to low fertilizer use, low-quality seeds, poor extension services, volatile weather resulting in frequent crop failures, and inadequate insurance schemes (FAO 2009; Schierhorn et al. 2014; Uzun et al. 2014; Kingwell et al. 2016).

\section{Climate Change}

The impact of climate change on RUK grain production potential varies across the different parts of this vast region (Dronin and Kirilenko 2011; Müller et al. 2016; Fehér et al. 2017).9 The northern parts may benefit from warmer weather and longer growing seasons, but the soil quality there limits growth potential. Production in the southern regions, which has most of the good soils, is likely to become more vulnerable with climate change, especially from a drop in precipitation.

\section{Production Potential}

Swinnen et al. (2017) review a series of studies on RUK grain production potential under various scenarios. Table 7.4 summarizes their conclusions. Under the recultivation scenario, grain area would expand by 8.5 million hectares, mostly in the Russian Federation, and this would result in an extra 12.5 million tons of RUK output. Closing the yield gap (the intensification scenario) to 60 percent of potential yield on existing croplands would generate additional grain production of 23.9 million tons (of which 12.2 million is in the Russian Federation, 7.7 million in Ukraine, and 4.0 million in

9 See Akramov, Park, and Ilyasov (2017) for possible climate change effects on Central Asian agriculture. 
TABLE 7.4 Potential wheat production in the Russian Federation, Ukraine, and Kazakhstan (RUK) under different scenarios

\begin{tabular}{lccc}
\hline & $\begin{array}{c}\text { Area } \\
\text { (million tons) }\end{array}$ & $\begin{array}{c}\text { Yield } \\
\text { (tons/hectare) }\end{array}$ & $\begin{array}{c}\text { Production } \\
\text { (million tons) }\end{array}$ \\
\hline Baseline & 77.6 & 2.1 & 161.5 \\
Recultivation & 94.7 & 2.0 & 174.0 \\
Intensification at 60\% of the yield potential & 77.6 & 2.4 & 185.4 \\
$\begin{array}{l}\text { Intensification at 60\% of the yield potential + } \\
\text { recultivation + climate change }\end{array}$ & 87.6 & 2.4 & 203.8 \\
$\begin{array}{l}\text { Growth in production } \\
\text { Intensification at 80\% of the yield potential }\end{array}$ & 77.6 & & $42.3 \%$ \\
Intensification at 80\% of the yield potential + & 87.6 & 3.2 & 246.9 \\
recultivation + climate change & & & 271.5 \\
Growth in production & & & $110.0 \%$ \\
\hline
\end{tabular}

Source: Authors' calculations based on Swinnen et al. (2017).

Kazakhstan). ${ }^{10}$ This potential seems realistic, partly because relatively small increases in input use could result in substantial yield growth. This output rise equals 34 percent of the average annual RUK grain exports during 20132015, which totaled 71 million tons. Closing the RUK yield gap to a more challenging 80 percent of the yield potential would increase grain production on existing cropland by 85.4 million tons, compared with the baseline, an increase of more than 50 percent.

Adding the impact of climate change to the intensification scenario generates a further 4-5 million tons of grain output, depending on the yield gap assumptions. This production rise comes from the area added to grain production in northern regions, despite low yields on the new land.

The combination of the three effects (recultivation of land, climate change, and closing of yield gaps) generates a total production of 203.8 million tons. The 60 percent intensification scenario yields an increase compared with baseline output of 42.3 million tons (26 percent). The (perhaps unobtainable) 80 percent intensification scenario generates total production of 271.5 million

10 In this scenario, the additional grain production in Ukraine is 63 percent of the additional output of the Russian Federation, while total area under grain cultivation in Ukraine is only 35 percent of the cultivated area in the Russian Federation. Yield gap closure in Ukraine generates more additional production relative to the Russian Federation because of both higher yield potential and higher yield gaps in Ukraine (see Figure 7.5b). Despite the higher share of grain cultivation in total sown area in Kazakhstan (16 percent higher than in the Russian Federation and Ukraine), the production potential in Kazakhstan on existing cropland is relatively small because of the low current yields and small yield gaps. 
tons of wheat, 110 million tons above current production (and a rise of 68 percent). ${ }^{11}$ In all scenarios, most of the gains come from yield growth.

In summary, output potential for grain in the RUK could be somewhere between 200 and 270 million tons per year (of which more than 120 to 160 million tons would be in the Russian Federation alone). This would be an increase of approximately 40 to 100 million tons above "current" (baseline) production, which implies that even under more pessimistic scenarios, the RUK could satisfy a substantial share of the projected increase in global wheat and grain demand.

\section{Will the RUK Be a Reliable Grain Supplier to ECA and the World?}

A key question is whether this production and export potential is also a reliable source of food for other countries. Grain is a major component in the diet of all ECA countries, and several of the poorer Central Asian and Caucasus countries rely heavily on imports from the Russian Federation, Ukraine, and Kazakhstan for their supply. For example, more than 50 percent of the grain consumed in Georgia and Armenia during the period 2010-2017 was imported, almost exclusively from the RUK (Figures 7.11 and 7.12).

Figure 7.13 shows that since 2000 RUK grain exports (net as well as gross) have increased dramatically, especially of wheat. ${ }^{12}$ Average annual RUK gross grain exports increased from 10.0 million tons in 1998-2000 to 71.3 million tons in 2013-2015. However, Figure 7.13 also shows that these countries' grain exports are quite volatile, especially compared with other major suppliers such as the United States and the EU. This unreliability of supply is important in assessing the RUK countries' potential to become a "world breadbasket," especially to food-insecure countries that rely on the imports.

One factor that reduces the RUK countries' grain export reliability is volatile weather, with bad conditions (such as high temperature or low precipitation) reducing the domestic surpluses available for export. Figure 7.13 shows how closely the annual volumes of RUK grain exports track the weatherdriven fluctuation in production. RUK trade policies (in particular, export restrictions) also contribute to their grain export volatility. A common catalyst for the export controls is the reduced domestic harvests from poor weather, which motivate governments to keep grain within the country. The controls

11 For comparison, EBRD and FAO (2008) project maximum grain production potential for the RUK countries of 230 million tons, a 42 percent increase over the same period.

12 Given that the RUK countries import little grain, their net grain export volumes are only slightly below their gross exports (for the RUK collectively, only 2 percent lower in 2013-2015). 
FIGURE 7.11 Import dependency for cereals

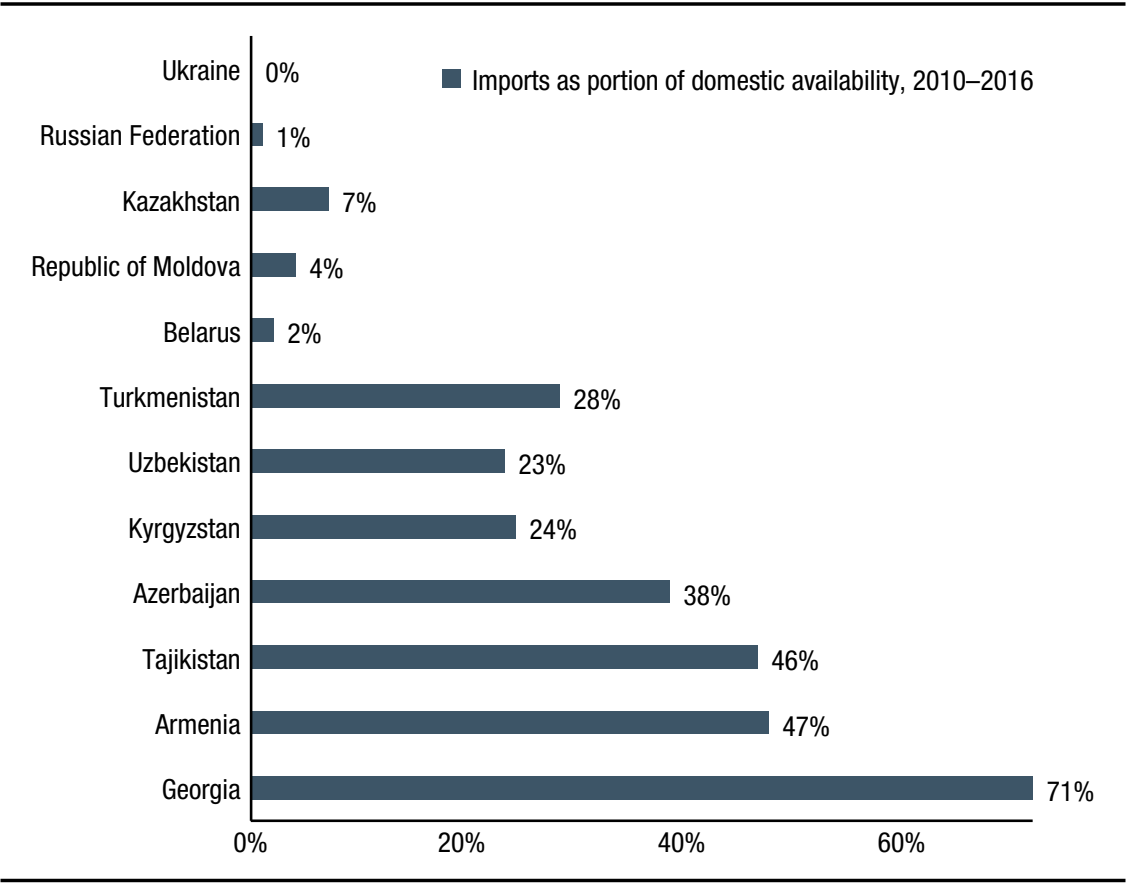

Source: FAO (2019).

FIGURE 7.12 Wheat imports by source country (\% of total wheat imports, ave. 2010-2017)

\begin{tabular}{|c|c|c|c|}
\hline & & $99 \%$ & $1 \%$ \\
\hline \multicolumn{4}{|l|}{ Kyrgyzstan } \\
\hline & $48 \%$ & $49 \%$ & $1 \% 2 \%$ \\
\hline \multicolumn{4}{|l|}{ Azerbaijan } \\
\hline & $20 \%$ & $74 \%$ & $5 \% 1 \%$ \\
\hline \multicolumn{4}{|l|}{ Georgia } \\
\hline & $4 \%$ & $91 \%$ & $3 \% 2 \%$ \\
\hline \multicolumn{4}{|l|}{ Armenia } \\
\hline & $\begin{array}{l}\text { Kazakhstan } \\
\text { Russian Federation } \\
\text { Ukraine } \\
\text { Rest of the world }\end{array}$ & & \\
\hline
\end{tabular}

Source: Data from FA0 (2019). 
FIGURE 7.13 Grain production and exports in the Russian Federation, Ukraine, and

\section{Kazakhstan}

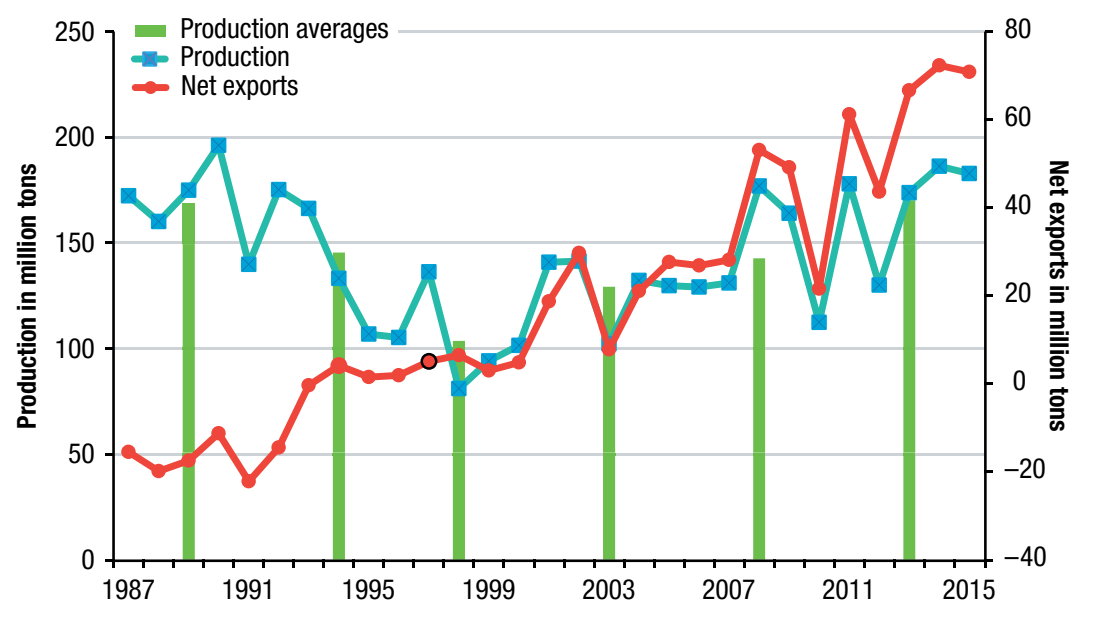

Source: USDA, Foreign Agricultural Service (2020).

Note: The bars give average annual grain production over the periods 1987-1991, 1992-1995, 1996-2000, 2001-2005, 2006-2010, and 2011-2015. Negative net grain exports are net imports.

are intended to mitigate the rise in domestic grain prices, and thereby help domestic food consumers and the feed-consuming livestock sector. For example, prompted by a poor harvest in 2010 , the Russian government banned all grain exports from August 2010 through June 2011.

During the surge in world agricultural and food prices in 2007-2008 and again in 2011-2012, all the ECA grain exporters (not just the RUK but also Tajikistan), as well as grain net-importers such as Belarus and Kyrgyzstan, imposed export restrictions to secure domestic supply and help domestic consumers, including the livestock sector (von Cramon and Raiser 2006; Dollive 2008; Jones and Kwiecinski 2010; World Bank 2011). An FAO study (Sedik 2013) found that a third of the surveyed ECA countries imposed agricultural export restrictions in some form, while a third reduced import taxes. ${ }^{13}$

The Russian Federation's economic crisis of 2015-2016, generated by a large drop in world oil prices (the Russian Federation's main export), subsequent depreciation of the ruble, geopolitical conflict with Ukraine and

13 Sedik $(2011,2013)$ showed that the harmful effect of RUK grain export restrictions on ECA importing countries was mitigated by their rapid shift toward greater imports of flour and other grain products whose exports were not restricted (or less so). 
the West, and an agricultural import ban imposed on the major Western countries, led to serious food price inflation. The Russian policy package to counter the price jump also included restricting grain exports (Liefert et al. 2019).

\section{Food and Nutrition Security in ECA}

Food prices spiked in 2007-2011, there was an economic crisis in 2009-2010, and real GDP and remittances declined as a result. ${ }^{14}$ Despite these occurrences, incomes in the ECA region, and thereby also food security, continue to improve steadily (although the income growth rates differ substantially between subregions). The income growth over the past 15 years has greatly reduced poverty, undernourishment, and micronutrient deficiency (Table 7.5 presents several food security indicators for selected ECA countries that experienced the strongest poverty decline). The ECA region has made major progress, and currently the majority of the ECA countries are below 2.5 percent prevalence of undernourishment. Nevertheless, undernourishment remains a challenge in a few of the Caucasus and Central Asian countries, in particular Tajikistan (where the prevalence is 30 percent).

In addition, poor diets and micronutrient deficiencies are a problem for a larger part of the ECA region. Poor diets can lead to an insufficient intake of nutrients, particularly iron, vitamin A, and zinc (FAO 2017a). Micronutrient deficiencies occur in both rich and poor ECA countries, but they are again more prevalent in the poorer countries of the Caucasus and Central Asia, as well as in the Republic of Moldova. This can be seen from high rates of stunting and anemia among children under five (Table 7.5).

As in other regions, economic transition and growing incomes generate a so-called nutritional transition where changes in diets and a more sedentary lifestyle lead to changes in nutritional and anthropomorphic outcomes (see Chapter 10). Now that food is becoming more readily available in the ECA region and undernutrition is less prevalent, a new challenge facing the ECA countries is growing obesity.

Figure 7.14 shows the relationship between income and nutritional problems in ECA. As per capita income grows, so too does overnutrition, in the form of overweight and obesity. According to FAO (2017a), overnutrition tends to increase alongside per capita incomes until the latter reach a level

14 In some ECA countries, remittances remain an important source of income. In Kyrgyzstan and Tajikistan they equal up to 30 percent of GDP (World Bank 2019). 
TABLE 7.5 Food security indicators for selected Eastern Europe and Central Asia (ECA) countries

\begin{tabular}{|c|c|c|c|c|c|c|c|c|}
\hline & \multicolumn{2}{|c|}{$\begin{array}{c}\text { GDP per capita } \\
\text { (PPP, in } 2011 \\
\text { international \$) }\end{array}$} & \multicolumn{2}{|c|}{$\begin{array}{l}\text { Poverty ratio at } \\
\$ 1.90 \text { a day in } \\
2011 \text { PPP (\%) }\end{array}$} & \multicolumn{2}{|c|}{$\begin{array}{c}\text { Prevalence of } \\
\text { undernourishment } \\
(\%)\end{array}$} & \multirow{2}{*}{$\begin{array}{c}\text { Prevalence } \\
\text { of anemia } \\
\text { in children } \\
<5 \text { years } \\
\text { old (\%) } \\
\\
2016\end{array}$} & \multirow{2}{*}{$\begin{array}{c}\text { Stunting } \\
\text { in children } \\
<5 \text { years } \\
\text { old (\%) } \\
\text { Latest } \\
\text { years } \\
\text { available }\end{array}$} \\
\hline & $\begin{array}{c}\ln \\
2018\end{array}$ & $\begin{array}{l}\text { Change } \\
\text { from } 2001 \\
(\%)\end{array}$ & $\begin{array}{c}\ln \\
2015\end{array}$ & $\begin{array}{l}\text { Change } \\
\text { from } \\
2001\end{array}$ & $\begin{array}{c}2014- \\
2016\end{array}$ & $\begin{array}{c}\text { Change } \\
\text { from } \\
1999-2001\end{array}$ & & \\
\hline Armenia & 9,178 & 185 & 2 & -17 & 24 & -19 & 32 & 21 \\
\hline Georgia & 10,152 & 170 & 8 & -13 & 7 & -7 & 24 & 11 \\
\hline Azerbaijan & 16,011 & 219 & $<1$ & -2 & $<2.5$ & -21 & 24 & 18 \\
\hline $\begin{array}{l}\text { Republic of } \\
\text { Moldova }\end{array}$ & 6,490 & 117 & 0 & -28 & 9 & -11 & 26 & 6 \\
\hline Kyrgyzstan & 3,447 & 60 & 3 & -34 & 6 & -10 & 38 & 13 \\
\hline Tajikistan & 3,061 & 140 & 5 & -26 & 30 & -12 & 31 & 27 \\
\hline Uzbekistan & 6,240 & 141 & 27 & -40 & 6 & -10 & 37 & 19 \\
\hline Turkmenistan & 17,129 & 211 & - & - & 6 & -3 & 28 & 20 \\
\hline
\end{tabular}

Source: FA0 (2017); FA0 (2019); World Bank (2019).

Note: $-=$ data not available; GDP = gross domestic product; PPP = purchasing power parity. Latest years available: Armenia 2010, Azerbaijan 2013, Georgia 2009, Kyrgyzstan 2014, Tajikistan 2012, Uzbekistan and Turkmenistan 2006, Albania 2009, Moldova 2004. Poverty data for Uzbekistan is for 2012 and 2002; Tajikistan data is for 2015 and 2003.

FIGURE 7.14 GDP per capita versus prevalence of obesity among males (+18)

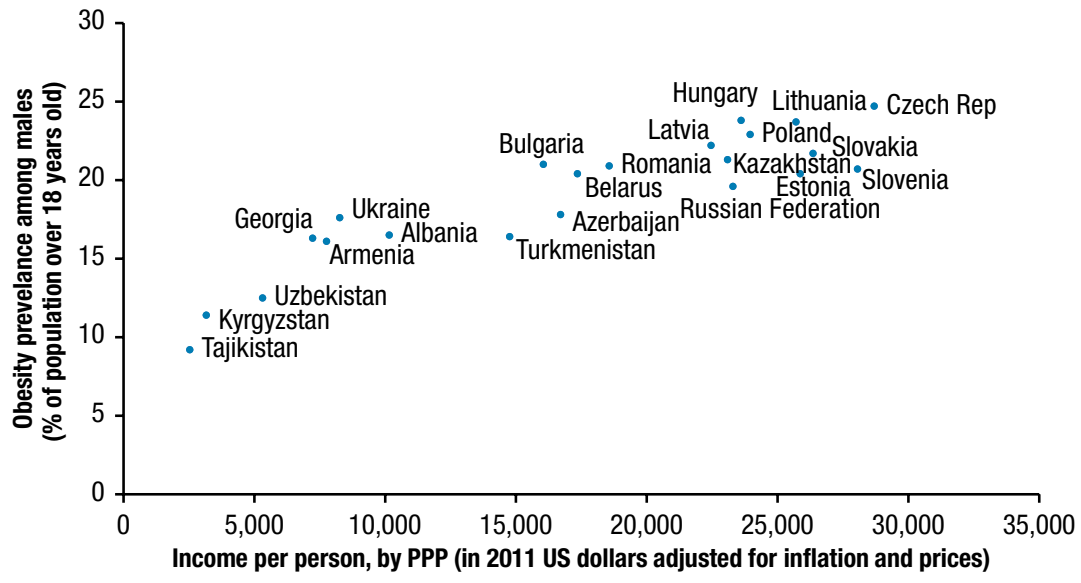

Source: WHO (2014); Gapminder (2019).

Note: "Obese" refers to individuals with body mass index greater than or equal to 30 . PPP = purchasing power parity. 
of between $\$ 30,000-\$ 40,000$ (in 2010 US dollars), after which the trend is reversed. Due to the nutritional transition currently underway in the ECA countries, combatting food insecurity in the future will no longer be a question of simply providing access to food, but also of providing access to healthy food in order to reduce micronutrient deficiencies and health risks caused by an overweight and obese population.

Numerous programs, policies, and strategies exist toward achieving food security, especially given that countries interpret food security in different ways. On this question, the ECA countries can be divided roughly into two groups: those that aim for food security through independence and food self-sufficiency, and those that seek to improve food availability without the use of food self-sufficiency targets (FAO 2015b).

Countries belonging to the first group include Belarus, Kazakhstan, Kyrgyzstan, the Russian Federation, Tajikistan, Turkmenistan, and Uzbekistan. In these countries, the concept of food security is primarily viewed as "food independence" or "food self-sufficiency," which is also reflected in the CIS Concept of Food Security, adopted by the CIS member countries in 2010. It states that "food security is the state of the economy of the countries in which their own production has to ensure food independence for not less than 80 percent of the annual demand in food production in accordance with physiological nutrition standards." ${ }^{15}$ The main policy directions to achieve self-sufficiency in these countries include (1) producer support for agricultural inputs; (2) trade interventions to favor domestic production and protect the country from imports, or discourage exports to protect domestic consumers from soaring prices; (3) price controls for basic food items; and (4) market interventions and management of commodity stocks (FAO 2015b). There are differences among countries in the mix of policy instruments and degree to which they are used to attain food self-sufficiency.

For example, we discussed earlier that large grain-exporting ECA countries such as the Russian Federation and Kazakhstan have used export restrictions to keep grain within their countries during periods of high world prices or bad weather that reduced the domestic harvest. Many ECA countries have also used agricultural import controls to protect domestic producers and promote self-sufficiency. For example, the Russian government regarded the largescale contraction of the livestock sector during the 1990s as a disaster that

15 Decision of Heads of Governments of CIS, "About the complex of joint efforts on increase in food security of the State Parties of the CIS," November 19, 2010 (available at https://zakon .rada.gov.ua/laws/show/997_m96\#Text). 
state policy should help reverse. In 2003, the government imposed a system of restrictive tariff rate quotas on imports of meat (beef, pork, and poultry). The government also began enacting an array of sanitary restrictions, including complete bans, on imports of meat and other livestock products (Liefert and Liefert 2012). These policies were consistent with the Russian Federation's Food Security Doctrine of 2010, which advocated agricultural import substitution and self-sufficiency.

Another policy is the use of state-run production and procurement of certain strategic commodities to fulfill food self-sufficiency goals. Elements of such a centrally planned system remain in Uzbekistan, Turkmenistan, and to some extent, Belarus, where state support is extended in the form of subsidized inputs to producers who fulfill the state order.

Although the approaches implemented toward achieving food selfsufficiency might be successful in strategic terms, they may not always be economically rational. This can be demonstrated in the case of Uzbekistan, where in pursuit of food self-sufficiency, wheat became another state-ordered crop. As a result, the area planted to wheat more than doubled between 1991 and 2017, most notably by shifting production to irrigated areas. Although this policy shift did increase wheat production, it came at a cost, as irrigation water was diverted away from high-value fruits and vegetables to wheat, a relatively low-value crop (FAO 2015b). Despite these efforts, the bulk of wheat consumed in Uzbekistan continues to be imported from Kazakhstan.

The second group, which includes Armenia, Azerbaijan, ${ }^{16}$ Georgia, the Republic of Moldova, and Ukraine, more closely follows the FAO approach to food security. This is outlined in the World Food Summit Plan of Action, which defines food security as being achieved "when all people, at all times, have physical and economic access to sufficient, safe and nutritious food to meet their dietary needs and food preferences for an active and healthy life." This interpretation of food security is much more inclusive and focuses more on improving food availability and access, food safety, and the nutritional state of the population. ${ }^{17}$ Policies adopted by these countries mainly focus on macroeconomic stability, investments in infrastructure, ensuring a reliable and stable food supply by both producing food domestically and recognizing that imports are necessary for food security and social development, supporting the agricultural sector within a liberal trade environment, finding new markets for agricultural products, and promoting exports (FAO 2015b).

16 With the exception of Azerbaijan's self-sufficiency in grain production.

17 For more detailed information on food-security-related policies in ECA, see FAO (2017a). 
Another way of influencing food and nutrition security is through agricultural subsidies that affect production and value chains. There have been attempts to assess the importance of these policies by either measuring the benefits and costs for those who are paying for the policies or looking at price regulations affecting consumers and producers. The Producer Support Estimate (PSE) and Consumer Support Estimate (CSE) are well-known indicators calculated by the Organisation for Economic Co-operation and Development (OECD). The nominal rate of assistance to agriculture (NRA) and the relative rate of assistance to agriculture (RRA) are well-known indicators, calculated by the World Bank, of the amount of support (taxation) to agriculture as a consequence of government regulations and subsidies (Anderson 2009; OECD 1999). ${ }^{18}$ These indicators are widely used in policy discussions and political economy analyses (see, for example, Anderson, Rausser, and Swinnen 2013). Unfortunately, for the Eurasian countries, updated PSE and CSE indicators are only available for the Russian Federation, Ukraine, and Kazakhstan. The average support given to agriculture in those countries (and thus the average tax on the budget and on food consumers) has fluctuated around 10 percent for the past 20 years and has stayed mostly between 0 and 20 percent. This means that, on average, farmers in those countries have benefited from government policies, but not extensively: on average, farms received around 10 percent more income than they would have without government interventions.

However, the average numbers hide important differences among commodities within the countries. For example, in Kazakhstan, livestock producers were subsidized in recent years (around 15 percent PSE), while maize, rice, and sunflower producers were taxed significantly (the PSE was between -20 and -80 percent). In the Russian Federation, the livestock sector was supported subtantially (around 25 percent PSE), while most grains and sunflowers had negative PSEs (between -5 and -30 percent) and were thus taxed.

For other countries, NRA and RRA indicators have been calculated for some commodities in Central Asia but have not been updated after 2004 (Anderson and Swinnen 2008; see the chapters by Christensen and Pomfret [2008] on Kyrgyzstan; by Pomfret [2008a] on Kazakhstan; and by Pomfret [2008b] on Tajikistan, Uzbekistan, and Turkmenistan). The (more limited) NRA studies on Central Asia point out the important differences

18 Negative PSE or CSE values imply taxation-see OECD (1999) for more details. NRA and RRA are indicators of the amount of support (taxation) to agriculture there is as a consequence of government regulations and subsidies—see Anderson (2009) for more details. 


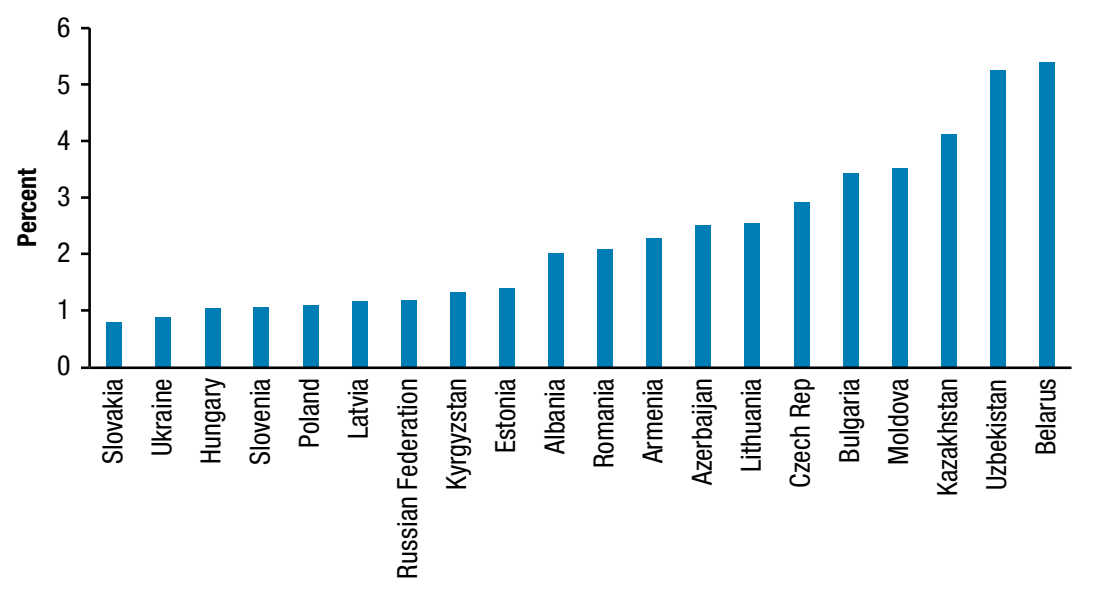

Source: Data from FA0 (2019).

among countries in their policies vis-à-vis the cotton sector. Cotton-a very important (export) commodity especially in Uzbekistan, Turkmenistan, and Tajikistan-was heavily taxed by the governments in these countries in the 1990s and 2000s, as it was an important source of government tax revenue. In contrast, it was much less taxed in other countries in the region where it was less important as an export commodity-such as in Kazakhstan and Kyrgyzstan (Pomfret 2008b).

Budget allocations are also indicators of government support, though they are more limited (because they do not provide information about transfers between consumers and producers through price and trade regulations). Figure 7.15 shows the average share of agriculture in total government expenditures between 2012 and 2017 in ECA. Some countries, like Belarus and Uzbekistan, spent over 5 percent of their state budgets on agricultural support. Others, like Slovakia, spent less than 1 percent.

\section{Conclusion}

Although the ECA countries are agriculturally heterogeneous in many ways, they share a common institutional history and, in certain respects, a common reform experience. The economic and institutional transformation that took place in the 1990s and 2000s had a dramatic effect on all these countries. However, the pace of transition from planned to market economy has differed 
greatly among them. Using a conceptual model, we illustrate and examine the key aspects of the agricultural transition process, some of which are still playing out in various ECA countries. In almost all countries, agricultural output fell substantially during the transition decade of the 1990s, especially in the livestock sector. Key reasons for the decline included the institutional and allocative disruptions and high transaction costs stemming from the move from planned to market economies, as well as the severe reduction in the large subsidies to agriculture under the planned system that maintained high-cost production. A dramatic decline in fertilizer use and crop prices in all ECA countries led to a strong drop in crop yields.

Agricultural output began to rebound in many ECA countries in the mid to late 1990s, and by the early 2000s production was increasing almost everywhere. Current agricultural output in ECA varies by country, from -30 to +30 percent of the pre-reform level. The output rebound has also varied by commodity. While wheat production declined during the 1990s and recovered strongly in the 2000s, especially in the RUK region, livestock production in many ECA countries still remains below the pre-reform level.

The rise in output was driven largely by input productivity growth. There were two general patterns involving farm structure and the rise in productivity and output. The first pattern included countries (such as Slovakia, the Czech Republic, and Hungary) where large farms dominated and most of the production increase came from growth in labor productivity. The second pattern occurred in poorer countries (such as Albania, Armenia, and Tajikistan) dominated by small farms, where the productivity of land (output per hectare) rose due to the intensive use of labor and other inputs. There are further countries (such as Poland) that have experienced some growth from an increase in both land and labor productivity.

Agricultural growth patterns are strongly related to farm structures. The ECA region is now characterized by strong heterogeneity of farm structures, and most countries have a mix of large- and small-scale farms. The emergence of different farm structures was largely "endogenous" to the transition process, due to differences in natural resources, commodity characteristics, and factor market imperfections.

Value-chain investments have played an important role in the growth of agricultural productivity in the ECA countries. Investments in value chains, often from foreign companies, led to major restructuring in production, trading, and marketing systems. Contracting and vertical coordination in value chains helped farmers to overcome production constraints through the 
provision of credit and inputs and resulted in major technology transfer, productivity growth, and improvements in production quality.

The transition process led to substantial changes in land use and a significant deterioration of infrastructure, most notably involving irrigation, which is of particular importance for agriculture in Central Asia and the Caucasus.

One of the main questions for agriculture in ECA is whether the RUK region has the potential to become a "breadbasket" to improve world food security. Some observers argue that by increasing yields or reusing 50-60 million hectares of abandoned land or both, the RUK region could boost the production and export of grain, and especially wheat. However, only a fraction of the abandoned land could actually be recultivated in a way that is economically profitable and environmentally sustainable, as most of it is in high-cost marginal regions where grain production is not commercially viable. On the other hand, we also project that the RUK countries will act on their more feasible potential to further increase grain yields, mainly by continuing to adopt better management practices that reduce waste, improve efficiency, and utilize Western technology.

Yet, due to climate change and weather volatility, uncertainties exist concerning the reliability of the RUK countries as grain export suppliers. Volatile RUK weather (both temperature and precipitation) creates major fluctuation in annual grain production, with bad weather reducing domestic surpluses for export. Low weather-driven harvests in turn often motivate the RUK governments to impose export controls to keep grain within the country in order to mitigate domestic price increases and thereby help food consumers and the feed-consuming livestock sector. For example, prompted by a poor harvest in 2010, the Russian government banned all grain exports from August 2010 through June 2011. During the surges in world agricultural and food prices in 2007-2008 and 2011-2012, all three RUK countries imposed various controls on grain exports (taxes, quotas, complete bans).

Food and nutrition security has improved substantially within the ECA region. Since around 2000, rising incomes have reduced poverty and undernourishment. However, in some of the poorer countries of the Caucasus and Central Asia, undernourishment remains a challenge, and even in countries with growing incomes, poor diets can cause micronutrient deficiencies. Also, as countries get richer, they experience the new problem, common to developed countries, of overnutrition, generating overweight and obesity.

Various programs, policies, and strategies exist for achieving food security in the ECA countries, depending on how they interpret food security. In 
countries where food security is primarily viewed as "food self-sufficiency," market interventionist agricultural policies have been employed to stimulate the domestic supply of staple foods, grains in particular. These policies were especially visible during the 2007-2012 period when food prices spiked on international markets. Another way of influencing food and nutrition security is through agricultural subsidies. However, not many indicators of agricultural support are calculated across the ECA countries that allow comparison, nor do they fully capture the important differences between commodities in different regions.

\section{References}

Abdullaev, I., and S. Atabaeva. 2012. "Water Sector in Central Asia: Slow Transformation and Potential for Cooperation." International Journal of Sustainable Society 4 (1-2): 103-112.

Abdullaev, I., J. Kazbekov, H. Manthritilake, and K. Jumaboev. 2010. "Water User Groups in Central Asia: Emerging Form of Collective Action in Irrigation Water Management." Water Resources Management 24 (5): 1029-1043.

Akramov, K., and N. Omuraliev. 2009. Institutional Change, Rural Services, and Agricultural Performance in Kyrgyzstan. IFPRI Discussion Paper 904. Washington, DC: IFRPI.

Akramov, K., A. Park, and J. Ilyasov. 2017. Review of Agricultural Development in Central Asia: Trends, Challenges, and Opportunities. Washington, DC: IFPRI.

Akramov, K., and G. Shreedhar. 2012. Economic Development, External Shocks, and Food Security in Tajikistan. IFPRI Discussion Paper 1163. Washington, DC: IFPRI.

Alcantara, C., T. Kuemmerle, M. Baumann et al. 2013. "Mapping the Extent of Abandoned Farmland in Central and Eastern Europe Using MODIS Time Series Satellite Data.” Environmental Research Letters 8: 035035.

Amirova, I., M. Petrick, and N. Djanibekov. 2019. "Long- and Short-Term Determinants of Water User Cooperation: Experimental Evidence from Central Asia." World Development 113: $10-25$.

Anderson, K. 2009. Distortions to Agricultural Incentives, A Global Perspective, 1955-2007. Washington DC: World Bank and Palgrave Macmillan.

Anderson, K., G. C. Rausser, and J. Swinnen. 2013. "Political Economy of Public Policies: Insights from Distortions to Agricultural and Food Markets." Journal of Economic Literature 51: 423-477.

Anderson, K., and J. Swinnen, eds. 2008. Distortions to Agricultural Incentives in Europe's Transition Economies. Washington, DC: World Bank. 
Babcock, B. A. 2015. "Extensive and Intensive Agricultural Supply Response." Annual Review of Resource Economics 7: 333-348.

Burkitbayeva, S., and J. Swinnen. 2018. "Smallholder Agriculture in Transition Economies." Journal of Agrarian Change 18 (4): 882-892.

Christensen, G., and R. Pomfret. 2008. “The Kyrgyz Republic.” In Distortions to Agricultural Incentives in Europe's Transition Economies, edited by K. Anderson and J. Swinnen. Washington DC: World Bank.

Dollive, K. 2008. The Impact of Export Restraints on Rising Grain Prices. US International Trade Commission, Office of Economics Working Paper 2008-09-A. Washington, DC.

Dronin, N., and A. Kirilenko. 2011. "Climate Change, Food Stress, and Security in Russia." Regional Environmental Change 11: 167-178.

Dries, L., E. Germenji, N. Noev, and J. Swinnen. 2009. “Farmers, Vertical Coordination, and the Restructuring of Dairy Supply Chains in Central and Eastern Europe." World Development 37 (11): 1742-1758.

Dries, L., and J. Swinnen. 2002. "Institutional Reform and Labor Reallocation during Transition: Theory Evidence from Polish Agriculture." World Development 3 (3): 457-474.

_. 2004. "Foreign Direct Investment, Vertical Integration and Local Suppliers: Evidence from the Polish Dairy Sector." World Development 32 (9): 1525-1544.

- 2010. "The Impact of Interfirm Relationships on Investment: Evidence from the Polish Dairy Sector." Food Policy 35 (2): 121-129.

EBRD (European Bank for Reconstruction and Development) and FAO (Food and Agriculture Organization of the United Nations). 2008. Fighting Food Inflation through Sustainable Investment. Agricultural Outlook. Investment Centre/EBRD Cooperation Programme. Report Series March 10. London.

EU Parliament. 2014. Family Farming in Europe, Challenges and Prospects: In-Depth Analysis. European Union.

Eurostat. 2018. Database. Accessed 2018. https://ec.europa.eu/eurostat/data/database.

FAO (Food and Agriculture Organization of the United Nations). 2009. The State of Agricultural Commodity Markets: High Food Prices and the Food Crisis_Experiences and Lessons Learned. Rome.

- 2015a. FAOSTAT database. Accessed 2015. http://faostat.fao.org.

-2015b. Regional Overview of Food Insecurity: Europe and Central Asia. Budapest.

- 2017a. Europe and Central Asia: Regional Overview of Food Insecurity. Budapest.

—.2017b. Food Security Indicators. Rome. www.fao.org/economic/ess/ess-fs/ess-fadata/en/\#. We-gWWVCL-Y. 
- 2019. FAOSTAT database. Accessed 2019. http://faostat.fao.org.

Fehér, I., J. Lehota, Z. Lakner, Z. Kende, C. Bálint, S. Vinogradov, and A. Fieldsend. 2017.

“Kazakhstan's Wheat Production Potential." In The Eurasian Wheat Belt and Food Security: Global and Regional Aspects, edited by S. Gomez y Paloma, S. Mary, S. Langrell, and P. Ciaian, 177-194. Switzerland: Springer.

Gapminder. 2019. Data. Accessed 2019. https://www.gapminder.org/data/.

Gataulina, E. A., V. Y. Uzun, A. V. Petrikov, and R. G. Yanbykh. 2005. "Vertical Integration in an Agroindustrial Complex: Agrofirms and Agroholdings in Russia." In The Dynamics of Vertical Coordination in Agrifood Chains in Eastern Europe and Central Asia, Case Studies, edited by J. F. M. Swinnen, 45-71. Washington, DC: World Bank.

Glauben, T., M. Belyaeva, I. Bobojonov et al. 2014. Eastern Breadbasket Obstructs Its Market and Growth Opportunities. IAMO Policy Brief 16. Halle, Germany: Leibniz Institute of Agricultural Development in Transition Economies.

Glowny Urzad Statystyczny. 2016. Online Statistical Database of the Central Statistical Office of the Republic of Poland. Accessed 2017. http://stat.gov.pl/en/.

Gow, H. R., D. H. Streeter, and J. Swinnen. 2000. "How Private Contract Enforcement Mechanisms Can Succeed Where Public Institutions Fail: The Case of Juhockur a.s." Agricultural Economics 23: 253-265.

Gow, H., and J. Swinnen. 1998. "Agribusiness Restructuring, Foreign Direct Investment, and Hold-Up Problems in Agricultural Transition." European Review of Agricultural Economics 25 (4): 331-350.

Hayami, Y., and V. W. Ruttan. 1971. Agricultural Development: An International Perspective. Baltimore: Johns Hopkins University Press.

IAMO (Leibniz Institute of Agricultural Development in Transition Economies). 2018. AGRICISTRADE. Accessed January 12, 2018. https://www.iamo.de/en/research/projects/ details/agricistrade/.

ILO (International Labour Organization). 2014. Global Employment Trends. www.ilo.org/global/ research/global-reports/global-employment-trends/2014/WCMS_234879/lang--en/index .htm.

Ioffe, G., T. Nefedova, and I. Zaslavsky. 2004. "From Spatial Continuity to Fragmentation: The Case of Russian Farming." Annals of the Association of American Geographers 94: 913-943.

Johnson, D. G., and K. Brooks, eds. 1983. Prospects for Soviet Agriculture in the 1980s. Bloomington, IN: Indiana University Press. 
Jones, D., and A. Kwiecinski. 2010. Policy Responses in Emerging Economies to International Agricultural Commodity Price Surges. OECD and Food, Agriculture and Fisheries Working Paper 34. Paris: Organisation for Economic Co-operation and Development.

Kamp, J., R. Urazaliev, P. F. Donald, and N. Hölzel. 2011. "Post-Soviet Agricultural Change Predicts Future Declines after Recent Recovery in Eurasian Steppe Bird Populations.” Biological Conservation 144: 2607-2614.

Kazstat. 2016. Statistical Yearbook. Almaty, Kazakhstan: Agency of Statistics of Kazakhstan. 2019. Statistics of Agriculture, Forestry, Hunting and Fisheries. Main Indicators. Accessed 2019. https://stat.gov.kz/official/industry/14/statistic/7.

Kingwell, R., C. Carter, M. P. Elliott, and P. White. 2016. Russia's Wheat Industry: Implications for Australia. Perth: Australian Export Grains Innovation Centre.

Kornai, J. 2000. “Ten Years After 'The Road to a Free Economy’: The Author's Self Evaluation.” Working paper. Cambridge, MA, US: Harvard University.

Kraemer, R., A. Prishchepov, D. Müller et al. 2015. "Long-Term Agricultural Land-Cover Change and Potential for Cropland Expansion in the Former Virgin Lands Area of Kazakhstan.” Environmental Research Letters 10: 054012.

Kurganova, I., V. Lopes de Gerenyu, and Y. Kuzyakov. 2015. "Large-Scale Carbon Sequestration in Post-Agrogenic Ecosystems in Russia and Kazakhstan.” Catena 133: 461-466.

Lambin, E. F., H. Gibbs, L. Ferreira et al. 2013. "Estimating the World's Potentially Available Cropland Using a Bottom-Up Approach.” Global Environmental Change 23: 892-901.

Lambin, E. F., and P. Meyfroidt. 2011. "Global Land Use Change, Economic Globalization, and the Looming Land Scarcity." Proceedings of the National Academy of Sciences 108: 3465-3472.

Larsson, S., and C. Nilsson. 2005. "A Remote Sensing Methodology to Assess the Costs of Preparing Abandoned Farmland for Energy Crop Cultivation in Northern Sweden.” Biomass and Bioenergy 28 (1): 1-6.

Lerman, Z. 2010. "Agricultural Recovery and Individual Land Tenure: Evidence from Central Asia." In Changing Landscape of European Agriculture. Essays in Honour of Professor Csaba Csaki, edited by I. Ferto, C. Forgacs, and A. Jambor, 95-113. Budapest: Agroinform.

Liefert, W. M. 2002. "Comparative (Dis?)Advantage in Russian Agriculture.” American Journal of Agricultural Economics 84 (3): 762-767.

Liefert, W. M., and O. Liefert. 2012. "Russian Agriculture during Transition: Performance, Global Impact, and Outlook." Applied Economic Perspectives and Policy 34 (1): 37-75.

.2015. "Russia's Potential to Increase Grain Production by Expanding Area." Eurasian Geography and Economics 56 (5): 505-523. 
Liefert, W. M., O. Liefert, R. Seeley, and T. Lee. 2019. “The Effect of Russia's Economic Crisis and Import Ban on Its Agricultural and Food Economy." Journal of Eurasian Studies 10 (2): 119-135.

Liefert, W. M., and J. Swinnen. 2002. Changes in Agricultural Markets in Transition Economies. Agricultural Economics Report AER806. Economic Research Service. Washington, DC: US Department of Agriculture.

Meyfroidt, P., F. Schierhorn, A. V. Prishchepov, D. Müller, and T. Kuemmerle. 2016. "Drivers, Constraints and Trade-Offs Associated with Recultivating Abandoned Cropland in Russia, Ukraine and Kazakhstan." Global Environmental Change 37: 1-5.

Müller, D., A. Jungadreas, F. Koch, and F. Schierhorn. 2016. Impact of Climate Change on Wheat Production in Ukraine. Agricultural Policy Report. Kiev: German-Ukrainian Agricultural Policy Dialogue.

Nefedova, T. G. 2016. "Russian Agricultural Resources and the Geography of Their Use in Import-Substitution Conditions." Regional Research Russia 6: 292-303.

Noev, N., L. Dries, and J. Swinnen. 2009. "Institutional Change, Contracts, and Quality in Transition Agriculture: Evidence from the Bulgarian Dairy Sector." Eastern European Economics 47 (4): 62-85.

OECD (Organisation for Economic Co-operation and Development). 1999. Agricultural Policies in Emerging and Transition Economies. Paris.

Pomfret, R. 2008a. “Kazakhstan.” In Distortions to Agricultural Incentives in Europe's Transition Economies, edited by K. Anderson and J. Swinnen. Washington, DC: World Bank.

_. 2008b. “Tajikistan, Turkmenistan and Uzbekistan.” In Distortions to Agricultural Incentives in Europe's Transition Economies, edited by K. Anderson and J. Swinnen. Washington, DC: World Bank.

Potapov, P. V., S. A. Turubanova, A. Tyukavina, A. M. Krylov, J. L. McCarty, V. C. Radeloff, and M. C. Hansen. 2015. "Eastern Europe’s Forest Cover Dynamics from 1985 to 2012 Quantified from the Full Landsat Archive." Remote Sensing of Environment 159: 28-43.

Rosstat. 2016. Statistics. Moscow: Federal Service of State Statistics of the Russian Federation. Accessed 2016. https://gks.ru/statistic.

- 2019. Official statistics. Agriculture, Hunting and Forestry. Accessed 2019. https://gks.ru/ enterprise_economy.

Schierhorn, F., D. Müller, T. Beringer, A. V. Prishchepov, T. Kuemmerle, and A. Balmann. 2013. "Post-Soviet Cropland Abandonment and Carbon Sequestration in European Russia, Ukraine, and Belarus." Global Biogeochemical Cycles 27: 1175-1185. 
Schierhorn, F., D. Müller, A. V. Prishchepov, M. Faramarzi, and A. Balmann. 2014. “The Potential of Russia to Increase Its Wheat Production through Cropland Expansion and Intensification." Global Food Security 3: 133-141.

Sedik, D. 2011. "Food Security and Trade in the ECA Region." Paper presented at the Course on Food and Agricultural Trade for ECA, Vienna, February 7-10.

_ 2013. "The New Wheat Exporters of Eurasia and Volatility." In The Eurasian Wheat Belt and Food Security: Global and Regional Aspects, edited by S. Gomez y Paloma, S. Mary, S. Langrell, and P. Ciaian, 119-138. Switzerland: Springer.

Serova, E. 2007. "Agro-Holdings: Vertical Integration in Agro-Food Supply Chains in Russia." In Global Supply Chains, Standards and the Poor: How the Globalization of Food Systems and Standards Affects Rural Development and Poverty, edited by J. Swinnen, 188206. Wallingford, UK: CABI.

Swinnen, J. 2009. "Reforms, Globalization, and Endogenous Agricultural Structures." Agricultural Economics 40 (6): 719-732.

Swinnen, J., S. Burkitbayeva, F. Schierhorn, A. Prishchepov, and D. Muller. 2017. "Production Potential in the 'Bread Basket' of Eastern Europe and Central Asia." Global Food Security 14: $38-53$.

Swinnen J., L. Dries, and K. Macours. 2005. “Transition and Agricultural Labor.” Agricultural Economics 32 (1): 15-34.

Swinnen, J., and S. Rozelle. 2006. From Marx and Mao to the Market. The Economics and Politics of Agricultural Transition. Oxford: Oxford University Press.

Ukrstat. 2016. Statistical Yearbook. State Committee of Statistics. Kiev, Ukraine.

-2019. Statistical observations. Economic statistics. Agriculture, forestry and fishery. Accessed 2019. http://www.ukrstat.gov.ua.

USDA (US Department of Agriculture), Foreign Agricultural Service. 2020. FAS Production, Supply, and Distribution Online (USDA PS\&D). https://apps.fas.usda.gov/psdonline/app/ index.html\#/app/home.

Uzun, V., V. Saraikin, E. Gataulina, N. Shagayda, R. Yanbykh, S. Mary, and S. Gomez y Paloma. 2014. Prospects of the Farming Sector and Rural Development in View of Food Security: The Case of the Russian Federation. Scientific and Technical Research Reports. European Commission.

Van Herck, K., and J. Swinnen. 2015. “Small Farmers, Standards, Value Chains, and Structural Change: Panel Evidence from Bulgaria.” British Food Journal 117 (10): 2435-2464. 
von Cramon, S., and M. Raiser. 2006. The Quotas on Grain Exports in Ukraine: Ineffective, Inefficient, and Non-Transparent. Kiev, Ukraine: Institute for Economic Research and Policy Consulting in Ukraine, German Advisory Group on Economic Reform.

Vranken, L., K. Macours, N. Noev, and J. Swinnen. 2011. "Property Rights Imperfections and Asset Allocation: Co-ownership in Bulgaria." Journal of Comparative Economics 39: 159-175.

Wegerich, K. 2008. “Blueprints for Water User Associations' Accountability versus Local Reality: Evidence from South Kazakhstan.” Water International 33 (1): 43-54.

World Bank. 2005. The Dynamics of Vertical Coordination in Agrifood Chains in Eastern Europe and Central Asia. Washington, DC.

—.2011. Rising Food and Energy Prices in Europe and Central Asia. Washington, DC.

_.2019. World Development Indicators database. Accessed February 12, 2019. https://data. worldbank.org/data-catalog/world-development-indicators.

World Health Organization (WHO). 2014. Global Health Observatory (GHO) data. www.who .int/gho/ncd/risk_factors/overweight/en/.

Zinzani, A. 2015. "Irrigation Management Transfer and WUAs' Dynamics: Evidence from the South-Kazakhstan Province." Environmental Earth Sciences 73: 765-777. 